\title{
The Tropospheric Distribution of Carbon Monoxide as Observed During the Tropoz II Experiment
}

\author{
J. ROTHS ${ }^{1,2}$ and G. W. HARRIS ${ }^{3}$ \\ Max Planck Institute for Chemistry, PO Box 3060, 55020 Mainz. Germany
}

\begin{abstract}
As part of the TROPOZ II large-scale measurement campaign in January 1991 we deployed a Four Laser Airborne Infra Red (FLAIR) tunable diode laser spectrometer on board a Caravelle 116 research aircraft. We report here in situ $\mathrm{CO}$ measurements which were obtained with one of the four channels of the FLAIR instrument at a time resolution of either one or two minutes. The flight route of the TROPOZ II campaign followed the Atlantic coasts of North America, the Pacific and Atlantic coasts of South America and the Atlantic coasts of West Africa and Europe. A total of $48 \mathrm{CO}$ vertical profiles extending from the surface to $10.5 \mathrm{~km}$ altitude were obtained. In the meridional direction adjacent profiles were separated by less than $10^{\circ}$ latitude. Polewards of $30^{\circ} \mathrm{S}$ the $\mathrm{CO}$ distribution was very homogeneous with a mean mixing ratio of $55 \mathrm{ppbv}$. Between $30^{\circ} \mathrm{S}$ and the equator, the CO mixing ratio above $8 \mathrm{~km}$ altitude ranged up to $130 \mathrm{ppbv}$ and was $20-60 \mathrm{ppbv}$ higher than in the mid free troposhere. Three day backward trajectories for these $\mathrm{CO}$ rich aimasses originated over Amazonia. Earlier trace gas measurements as well as circulation studies suggested that these airmasses were of Northern Hemispheric origin and had been rapidly convected to the upper troposphere over central South America. The influence of biomass burning is clearly apparent from the measurements performed at $10^{\circ} \mathrm{N}$ on the African side of the Atlantic with $\mathrm{CO}$ mixing ratios being $100-300 \%$ higher than on the Central American side. CO mixing ratios further north ranged from 80 to $130 \mathrm{ppbv}$ in the free troposphere and increased to $130-150 \mathrm{ppbv}$ at lower altitudes.
\end{abstract}

Key words: carbon monoxide, airborne measurements, large-scale tropospheric distribution, interhemispheric exchange, biomass burning, tunable diode lasers, measurement intercomparison.

\section{Introduction}

It is well established that carbon monoxide has an important role in the chemistry of the global troposphere. On a global scale, the reaction between carbon monoxide and the hydroxyl radical $(\mathrm{OH})$ is the dominant reaction for the hydroxyl radical, which itself is responsible for initiating photochemical oxidation cycles in which most atmospheric trace gases are involved. In the Northern Hemisphere, mean mixing ratios of carbon monoxide were reported to be increasing at a rate of 0.7$1 \%$ per year in the eighties (Khalil and Rasmussen, 1988; Zander et al., 1989), while more recent trend analyses (Novelli et al., 1994; Khalil and Rasmussen, 1994) suggest a subsequent decrease beginning in the late eighties. It is presently 
an open question whether these changes result from variations in source strengths for $\mathrm{CO}$ or from changes in the oxidizing efficiency of the atmosphere, or from both.

Carbon monoxide has both natural and anthropogenic sources, but large uncertainties exist in quantification of the individual source strengths. Logan et al. (1981) estimate a $\mathrm{CO}$ emission of $400-1000 \mathrm{Tg} / \mathrm{yr}$ from fossil fuel use. Oxidation of organic components in sea water leads to a CO production of 10-180 Tg/yr (Conrad et al., 1982). Carbon monoxide is directly emitted from plants, in the order of 50-100 $\mathrm{Tg} / \mathrm{yr}$ (Warneck, 1988). Biomass burning is a very important source of $\mathrm{CO}$ which is estimated to be in the range of 280-1190 Tg/yr (Crutzen and Andreae, 1990). $\mathrm{CO}$ is also indirectly produced by the reaction of methane and higher hydrocarbons with the hydroxyl radical. Model calculations from Hough (1991) indicate that about $1000 \mathrm{Tg} / \mathrm{yr}$ are produced by $\mathrm{CH}_{4}$ oxidation and a $800 \mathrm{Tg} / \mathrm{yr}$ are produced by nonmethane hydrocarbon oxidation. The dominant removal mechanism for $\mathrm{CO}$ is oxidation by $\mathrm{OH}$ which, according to the calculations of Hough (1991), leads to a consumption of $\mathrm{CO}$ of $3150 \mathrm{Tg} / \mathrm{yr}$, while the consensus reported by IPCC 92 (Houghton et al., 1992) would suggest a lower figure near $2000 \mathrm{Tg} / \mathrm{yr} \mathrm{CO}$ destruction. The CO flux to soils is estimated to be $220 \mathrm{Tg} / \mathrm{yr}$ (Hough, 1991).

The global distribution of $\mathrm{CO}$ has been the subject of study for many years and a large variety of experimental techniques and platforms have been employed. (Wilkniss et al., 1973; Seiler, 1974; Gauntner et al., 1979; Heidt et al., 1980; Seiler and Fishman, 1981; Robinson et al., 1984; Reichle et al., 1986; DianovKlokov et al., 1989; Marenco et al., 1989; Reichle et al., 1990). The measurements described here were obtained during the French-German large-scale airborne campaign, TROPOZ II, which was aimed at the study of the meridional distribution of a large number of trace gases in the free troposphere. The $\mathrm{CO}$ data reported here considerably increase the existing database and may be of particular value for several reasons: The reliability of the data is proven by a comparison with a second, independent $\mathrm{CO}$ measurement technique on board the same aircraft. The data set spans the latitudinal range between $48^{\circ} \mathrm{N}$ and $55^{\circ} \mathrm{S}$ with a large number of vertical profiles obtained, and high temporal resolution. The observations were made in January, a time of year when other global distribution data is lacking, although in this season the largest interhemispheric difference in $\mathrm{CO}$ content of the free troposphere is to be expected (winter in the more polluted Northern Hemisphere with low photochemical activity; high photochemical activity in the less polluted Southern Hemisphere).

\section{Measurement Technique}

The $\mathrm{CO}$ measurements presented here were carried out on one channel of a specially constructed Four Laser Airborne InfraRed (FLAIR) instrument which had its first deployment during the TROPOZ II campaign. Instrument design and system characteristics are described in a separate paper (Roths et al., 1996, to be published). The FLAIR instrument, which is based on tunable diode laser absorption 
spectroscopy (TDLAS), is able to measure four trace gases simultaneously. This is achieved by using four lead-salt diode lasers, one for each species, and three computer-controlled, magnetically-driven movable mirrors which steer each of the four laser beams into the measurement cell in turn. The 6.41 -volume cell provides a $126 \mathrm{~m}$ optical path, using a multiple-reflection system, based on an improved White cell design. A $40 \mathrm{~m}^{3} / \mathrm{h}$ rotary pump, in combination with a pressure stabilization loop, pumps ambient air through the measurement volume at a flow rate in the range of 1.5-2.0 standard liter per minute (depending on the outside pressure and the setting of a manually adjustable needle valve in the inlet line) and maintains a constant pressure of 40 mbar within the cell. Each laser is selected in turn every $18 \mathrm{~s}$, which is on the order of the air exchange time in the cell. This makes sure that the same air sample is probed by each channel, resulting in a quasi-simultaneous measurement. When the CO channel is selected, it is active for $2.6 \mathrm{~s}$. Seven of these intervals are averaged for one measurement, resulting in an integration time of $18 \mathrm{~s}$ for $\mathrm{CO}$. The overall time resolution is $126 \mathrm{~s}$ for all four channels (for flights \#25 \#30 a time resolution of $54 \mathrm{~s}$ was selected). During TROPOZ II, the FLAIR system was configured to make high precision and high sensitivity measurements of carbon monoxide, hydrogen peroxide, formaldehyde, and nitrogen dioxide. The lead-salt diode laser which was used for carbon monoxide was operating at 4.825 $\mu \mathrm{m}$ wavelength, where a $\mathrm{CO}$ absorption line, which was found to be free from

interference, was identified. The inlet consisted of a $\frac{1}{4}$ " Teflon tube inserted into a stainless steel pipe. The inlet point was located $215 \mathrm{~mm}$ above the aircraft surface, outside the turbulent boundary layer. System calibration was typically performed three times for each flight, before take-off, and twice when flying at cruising altitude. For calibration and background spectra, zero-gas was supplied by adding a surplus of pure $\mathrm{N}_{2}$ from a pressure tank to the inlet line. A calibration gas flow of $5.4 \mathrm{sccm}$ of a commercially available working standard (supplied by Linde AG Höllriegelskreuth), containing $152 \mathrm{ppmv} \mathrm{CO}$ in $\mathrm{N}_{2}$, was added to the flow entering the measurement cell. For the $\mathrm{CO}$ data obtained during TROPOZ II the precision was determined to be $5.2 \%$, while the overall accuracy was determined to be 6.3\% (Roths, 1992), which is determined by the accuracy of the working standard ( $2 \%$ certified by the supplier) and the uncertainty of the gas flow meters and their read-out electronics.

\section{The Tropoz-II Campaign}

The FLAIR spectrometer was part of the TROPOZ II payload on board of the Caravelle 116 research aircraft operated by the French Centre d'Essais en Vol. Figure 1 shows the flight track and the airports used. Each descent (average time $20 \mathrm{~min}$.) and ascent (average time $30 \mathrm{~min}$.) provided the opportunity to measure a vertical profile of the trace gases. During flights \#15, \#22, \#25, \#26, \#27 and \#28 additional profiles without intermediate landings were flown, giving a total of 68 vertical profiles sampled during the mission. The distance between each pair 


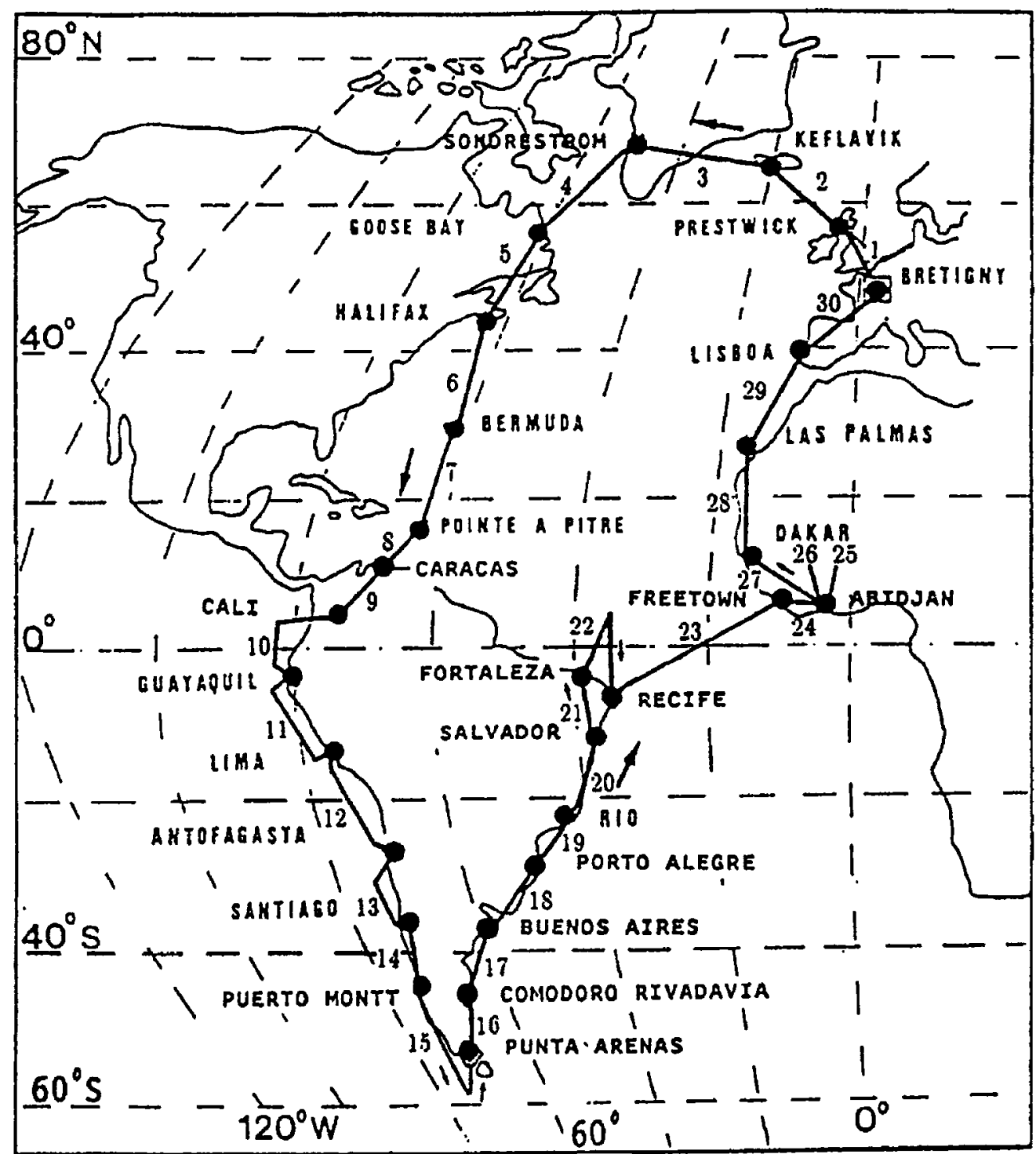

Figure 1. Flight track of the TROPOZ II mission (9 January 1991 - 1 Febnuary 1991).

of profiles was less than 10 degrees latitude. The cruising altitude was $10.5 \mathrm{~km}$ for most of the flights. The flight track has a meridional orientation covering a latitudinal range from $55^{\circ} \mathrm{S}$ to $68^{\circ} \mathrm{N}$. The mission started on 9 January 1991 in Brétigny (France) and was completed on 1 February 1991 also in Brétigny. On most days, two flight legs were flown per day, one in the morning and one in the afternoon.

Due to weight limitations no scientific personnel was on board the research aircraft and no measurements were conducted during the transatlantic flight (fiight \#23, Recife-Freetown) and flight \#24 (Freetown-Abidjan). During flights \#1-\#5 there was a leak in the inlet line of our FLAIR instrument allowing cabin air into the measurement volume and data collected during these flights are not reported. 
TDL measurements obtained during flight \#26 had to be discarded due to an error in calibration procedure. The FLAIR spectrometer was operational during all remaining 22 flights.

\section{Results}

A total of $1308 \mathrm{CO}$ measurements were taken during the campaign with the FLAIR spectrometer. Figures 2 to 17 show all the $\mathrm{CO}$ vertical profiles obtained during the TROPOZ II campaign. To assist in the interpretation of the measurements, potential temperature, relative humidity, wind velocity, and wind direction are also depicted in Figures 2-17.

\subsection{AIRBORNE INTERCOMPARISON}

During the TROPOZ II campaign carbon monoxide was also measured on board the research aircraft by the Laboratoire d'Aerologie, University of Toulouse, using gas chromatography (GC). Details of the GC method will be given in a forthcoming publication (Marenco, 1996). For intercomparison purposes, the time resolution of both the FLAIR and the GC data-sets have to be synchronized. The GC values are reported every 30 seconds and are representative for an air volume sampled for 5 seconds. Synchronization was achieved by averaging all GC-values obtained during the integration period of the FLAIR spectrometer. A total of 1038 data points was yielded by this procedure. The results of this in-flight intercomparison is shown in Figure 18. Note the large range of $\mathrm{CO}$ mixing ratios encountered, the values range from $40 \mathrm{ppbv}$ up to $380 \mathrm{ppbv}$, illustrating the high variability of carbon monoxide in the troposphere. Two distinct regions with high densities of datapoints can be recognized. One region is between 40 and $70 \mathrm{ppbv}$. As shown later, these measurements were taken exclusively in the Southern Hemisphere. The second range with high datapoint density is between 80 and $130 \mathrm{ppbv}$, these measurements are predominantly obtained in the free troposphere of the Northern Hemisphere. Measurements showing $\mathrm{CO}$ mixing ratios of more than $130 \mathrm{ppbv}$ are from samples taken within the planetary boundary layer.

The solid line in Figure 18 is a least-squares fit $(y=a+b x)$ to the data points and the dashed line gives the $y=x$ identity for reference. The statistics describing the regression line are given in Table I. The high correlation coefficient, together with the large number of samples describes the good correlation between the techniques. The intercept is not statistically different from zero, however the slope deviates significantly from unity. This arises from a $10 \%$ deviation in the working standards used, and is within the two sigma interval of the combined uncertainty stated by the suppliers of each working standard. 


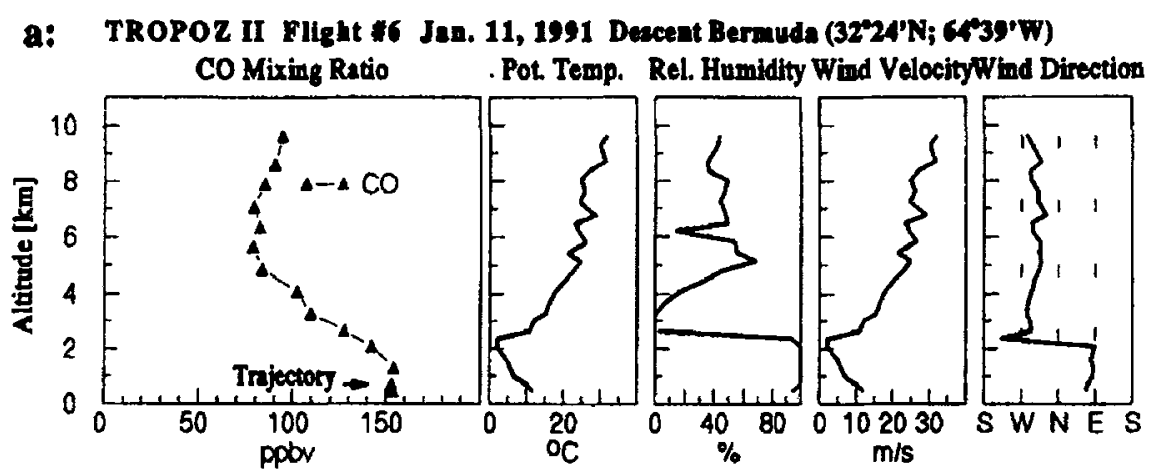

b: TROPOZ II Fight $\$ 7$ Jan. 12, 1991 Aacent Benmoda (32'24'N;G439'W)

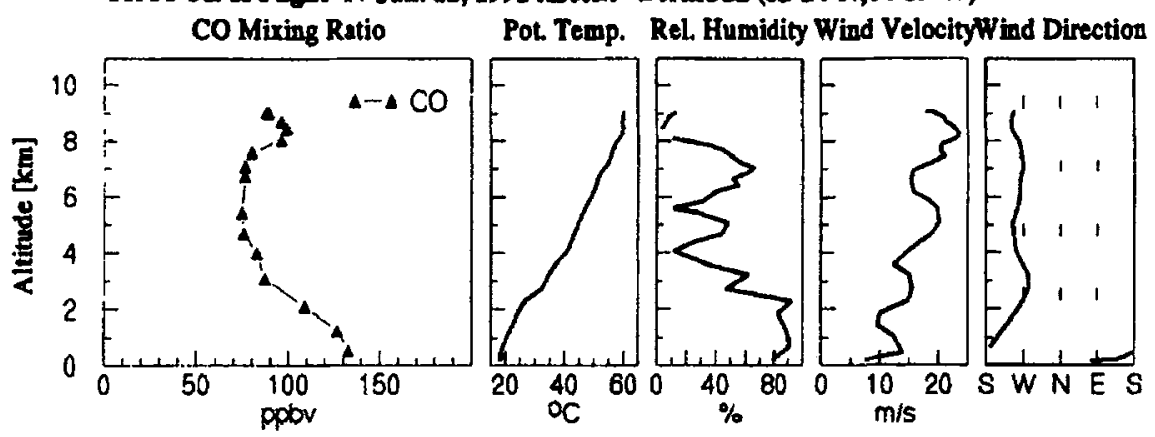

C: TROPOZ II Fight in Jan. 12, 1991 Deseest Pointe ì Pitre (10\%1'N;61'45' W)

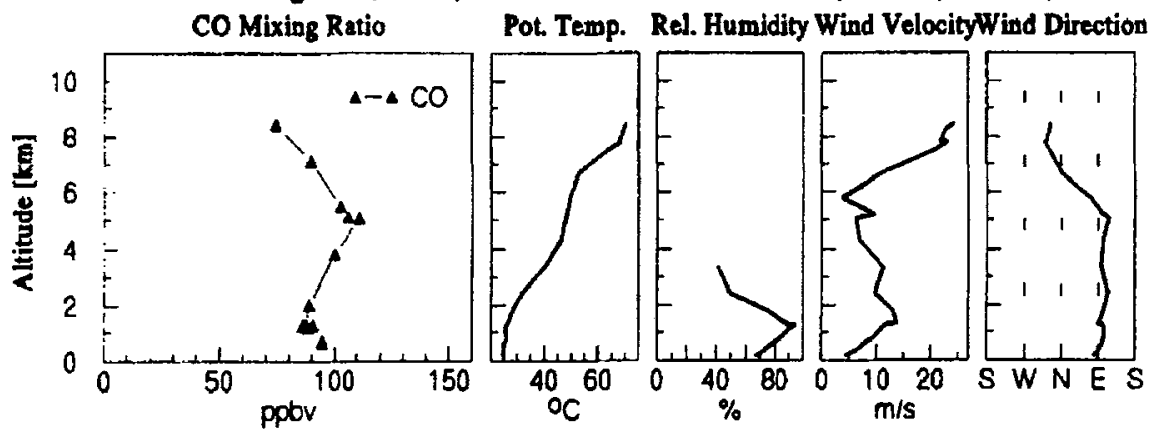

Figure 2. Vertical profiles of $\mathrm{CO}$, potential temperature, relative humidity, wind velocity, and wind direction for (a) approaching Bermuda (landing 23h25 UT, 19h25 local time), (b) ascent from Bermuda (take-off 18h12 UT, 14h12 local time) and (c) approaching Pointe à Pitre (landing $21 \mathrm{~h} 21 \mathrm{UT}, 17 \mathrm{~h} 21$ local time).

\subsection{MEASUREMENTS SOUTH OF $30^{\circ} \mathrm{S}$}

We begin the discussion of the $\mathrm{CO}$ data set with the measurements made during the southern part of the campaign. This comprises the descent to Santiago (flight $\# 13$, Figure 6b), flights \#14 to \#17 (Figures $6 \mathrm{c}$ to $8 \mathrm{c}$ ) and the ascent from Buenos Aires (flight \#18, Figure 9a). During all these flights the dominant wind direction is West. A common characteristic of these flights are the low and constant $\mathrm{CO}$ mixing ratios between 50 and $60 \mathrm{ppbv}$ in the free troposphere. Only at low altitudes near the airports Antofagasta, Santiago and Buenos Aires, higher $\mathrm{CO}$ mixing ratios were observed, which can very likely be attributed to local anthropogenic sources. 


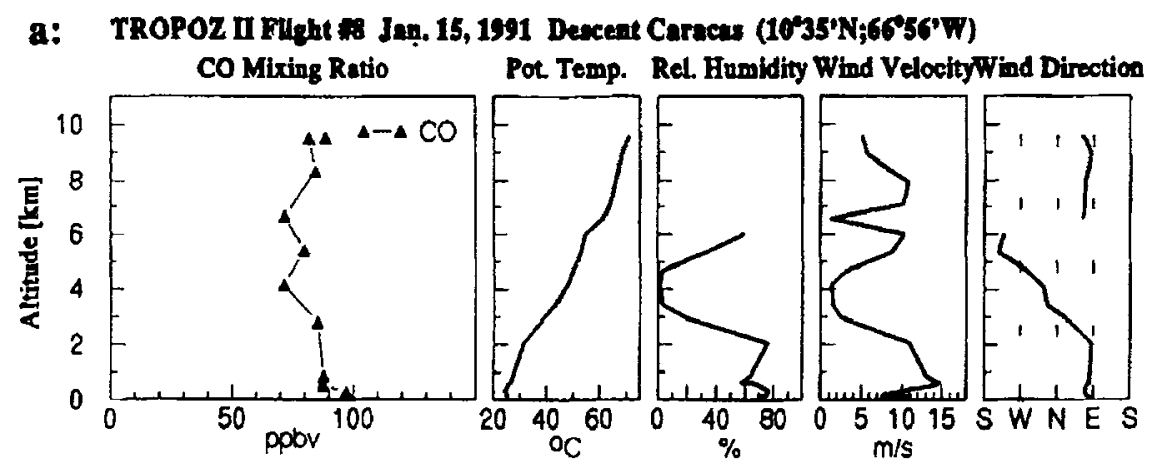

b: TROPOZ II Flight \$ Jan. 15, 1991 Accent Caraces (1035'N;6656'W) Co Mixing Ratio Pot Temp. Rel. Humidity Wind Velocity Wind Direction

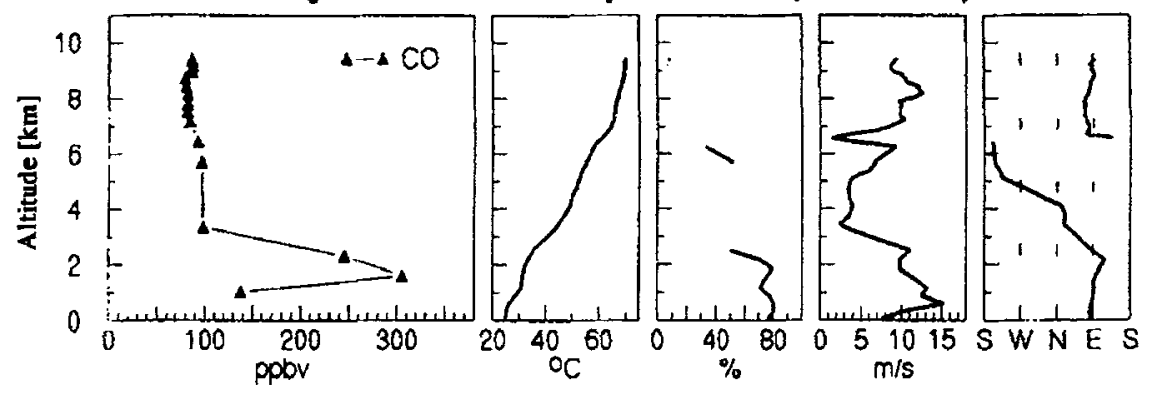

c: TROPOZ II Flight \#9 Jan. 15, 1991 Descent Call (03221'N;76'30'W)

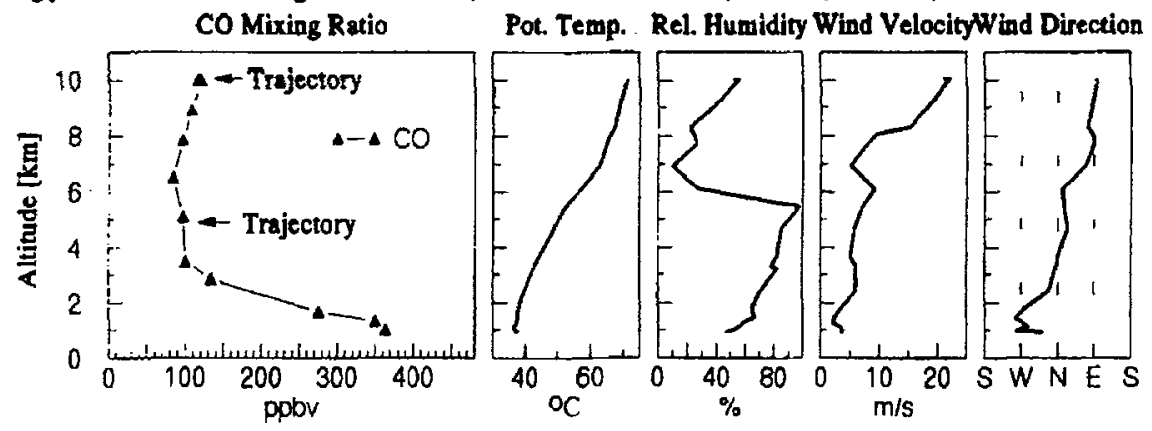

Figure 3. Same as Figure 2 but for (a) approaching Caracas (landing 16h42 UT, 12h42 local time), (b) ascent from Caracas (take-off 18h30 UT, $15 \mathrm{~h} 30$ local time), and (c) approaching Cali (landing $20 \mathrm{~h} 43 \mathrm{UT}, 15 \mathrm{~h} 43$ local time).

Table I. Parameters of the linear regression line shown in Figure 18, characterizing the inter-comparison of CO-TDL and CO-GC measurements performed during TROPOZ II

\begin{tabular}{ll}
\hline Parameter & Value \\
\hline$a$ (intercept) & $5.1 \mathrm{ppbv}$ \\
$\sigma_{\mathrm{a}}$ & $\pm 10.4 \mathrm{ppbv}$ \\
$b$ (slope) & 0.900 \\
$\sigma_{\mathrm{b}}$ & \pm 0.008 \\
$r$ (correlation coefficient) & 0.965 \\
$N$ (number of data points) & 1038 \\
\hline
\end{tabular}



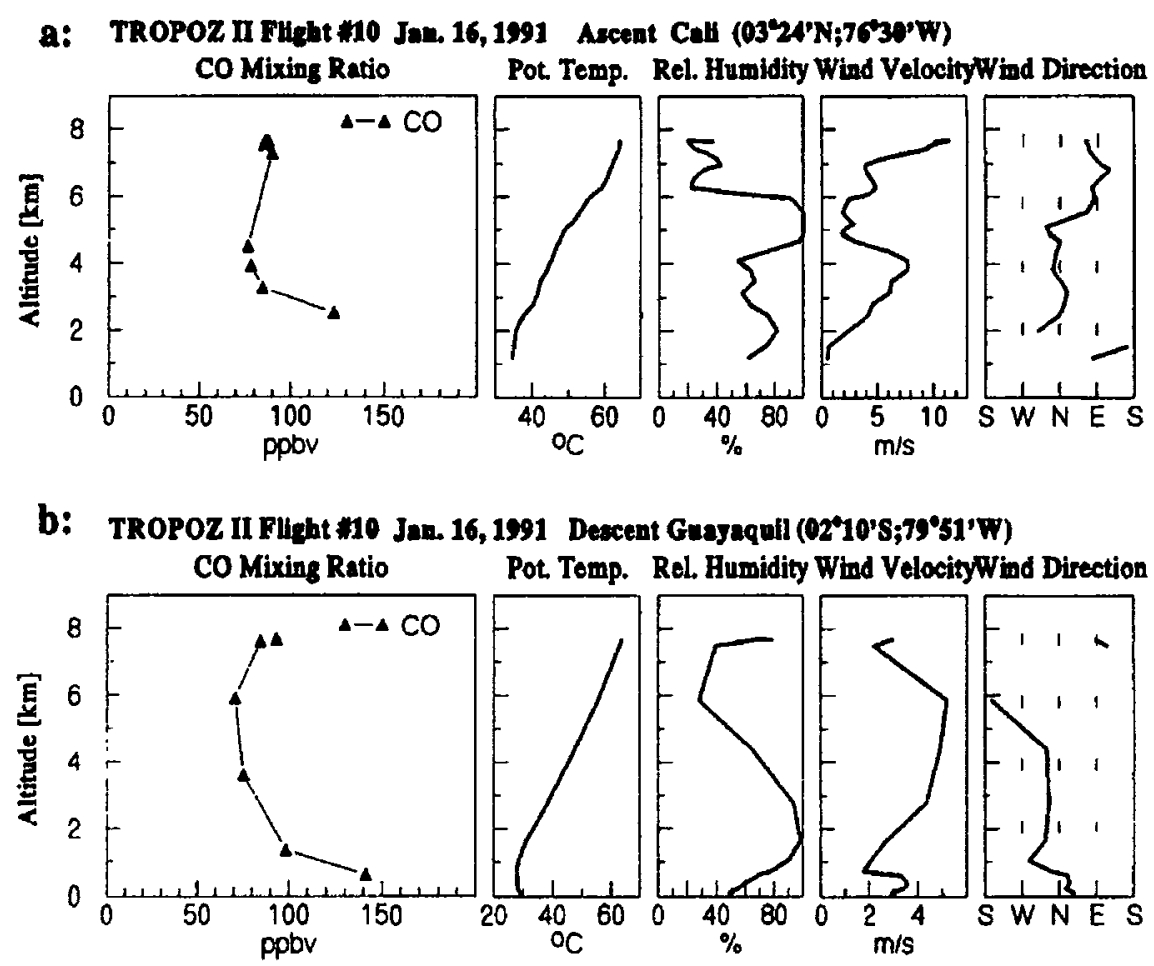

C: TROPOZ II Flight \#11 Jan, 16, 1991 Ascent Guayaquil (02'10'S;7951'W)

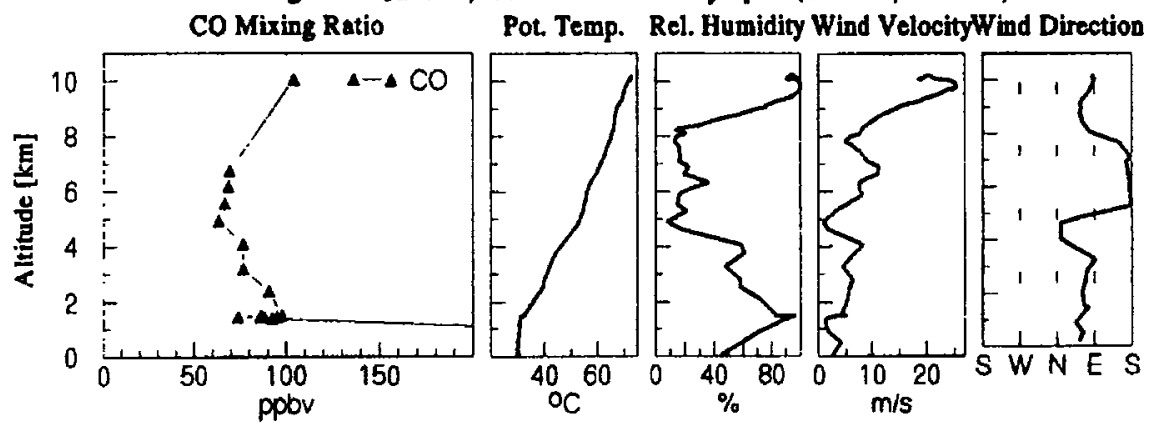

Figure 4. Same as Figure 2 but for (a) ascent from Cali (take-off 16h35 UT, $11 \mathrm{~h} 35$ local time), (b) approaching Guayaquil (landing 17h59 UT, $12 \mathrm{~h} 59$ local time), and (c) ascent from Guayaquil (take-off $20 \mathrm{h07}$ UT, $15 \mathrm{~h} 07$ local time).

The vertical profiles in the free troposphere show only small variations in the $\mathrm{CO}$ mixing ratio (less than $10 \mathrm{ppbv}$ ) with altitude. The low variability in the $\mathrm{CO}$ mixing ratio is also illustrated in the histogram in Figure 19. The bars represent the number of $\mathrm{CO}$ measurements within a $10 \mathrm{ppbv}$ interval. All $203 \mathrm{CO}$ measurements obtained south of $30^{\circ} \mathrm{S}$ are included in Figure 19. The distribution has a shape which is close to a Gauss function. The mean value from all measurements performed in the free troposphere is $\langle\mathrm{CO}\rangle=54.6 \mathrm{ppbv}$ and the standard deviation is $7.0 \mathrm{ppbv}$, which is slightly larger than the precision of the instrument. Airborne, altitude-resolved CO measurements are very limited in the Southern Hemisphere. Seiler and Fishman (1981) reported measurements made during July and August 1974 and Marenco et 

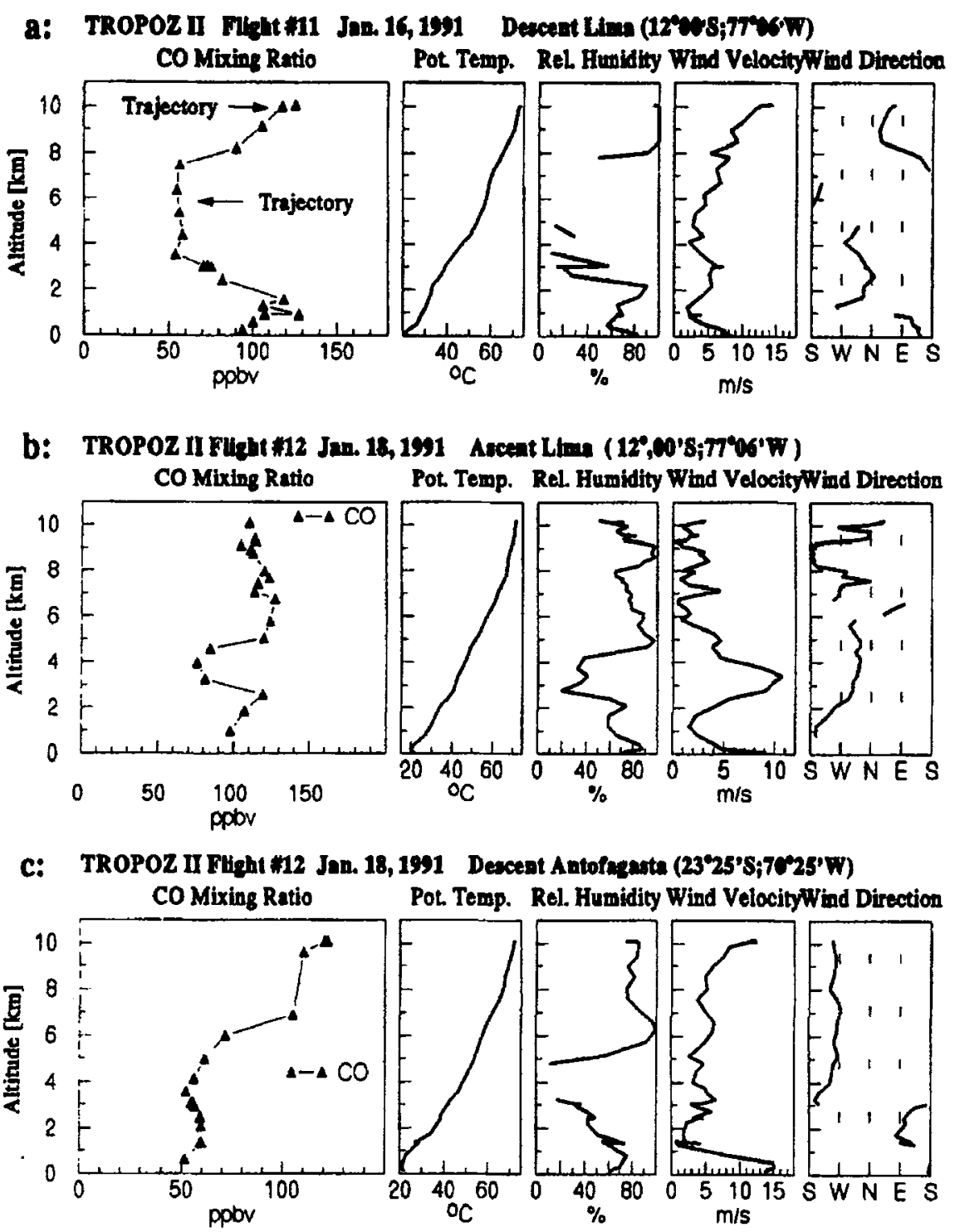

Figure 5. Same as Figure 2 but for (a) approaching Lima (landing 22h45 UT, 17h45 local time), (b) ascent from Lima (take-off 16h01 UT, 11 h0l local time), and (c) approaching Antofagasta (landing 18h33 UT, 14h33 local time).

al. (1989) reported measurements made in June 1984. Both campaigns followed nearly the same flight track as the TROPOZ II mission along the western coastlines of South America. They also measured very constant $\mathrm{CO}$ mixing ratios with altitude but their mean $\mathrm{CO}$ values are considerably higher, in the range of 70-80 ppbv. That can be attributed to the annual variation in the $\mathrm{CO}$ mixing ratio in the Southern Hemisphere, which is observed by several ground-based $\mathrm{CO}$ monitoring stations located south of $30^{\circ} \mathrm{S}$ (Cape Point: Seiler et al., 1984; Scheel et al., 1990; Brunke et al., 1990; Cape Grim: Fraser et al., 1991; Novelli et al., 1994).

Figure 7c shows a profile obtained south of Punta Arenas at $55^{\circ} \mathrm{S}$. Up to 8 $\mathrm{km}$ altitude constant $\mathrm{CO}$ mixing ratios of about $55 \mathrm{ppbv}$ are obtained but above 


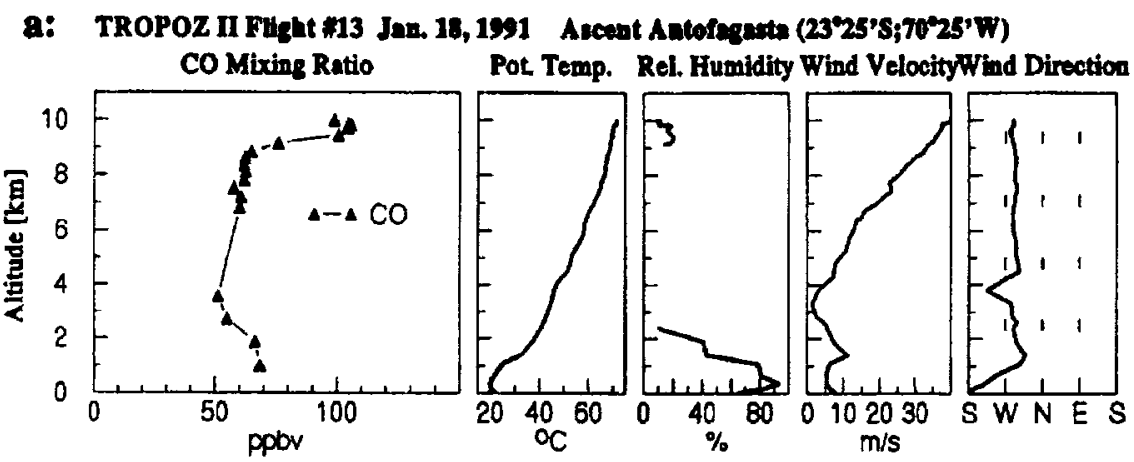

b: TROPOZ II Fitght 113 Jan. 18, 1991 Descent Santioso (33'22'S;7046'W)

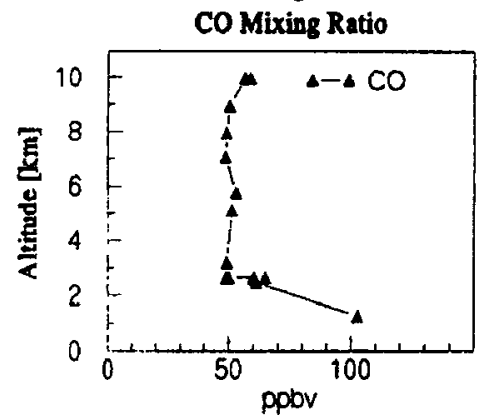

Pot Temp. Rel. Humidity Wind VelocityWind Direction

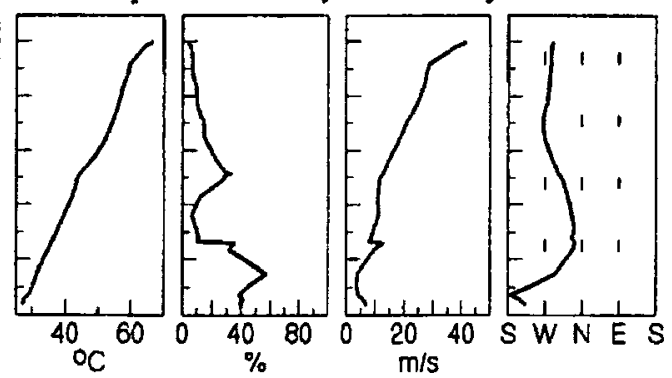

C: TROPOZ II Flight \#14 Jan. 21, 1991 Ascent Santingo (33²2'S;70'46'W)

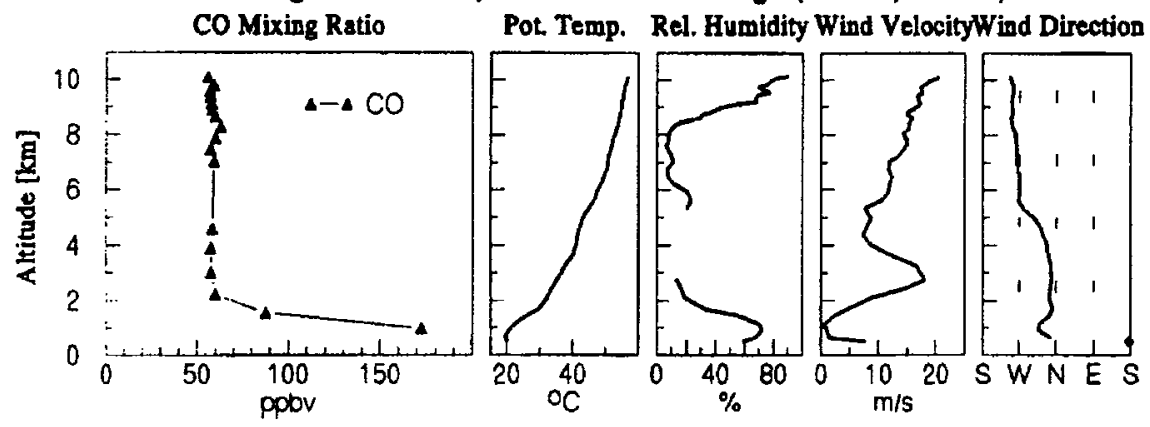

Figure 6. Same as Figure 2 but for (a) ascent from Antofagasta (take-off 20h28 UT, 16h28 local time), (b) approaching Santiago (landing $22 \mathrm{~h} 27 \mathrm{UT}, 18 \mathrm{~h} 27$ local time), and (c) ascent from Santiago (take-off $13 \mathrm{~h} 15 \mathrm{UT}, 9 \mathrm{~h} 15$ local time).

$8 \mathrm{~km}$ a decrease in the $\mathrm{CO}$ mixing ratio is observed. The three data points taken above $8 \mathrm{~km}$ altitude are the lowest $\mathrm{CO}$ mixing ratios measured during the whole campaign and gave a mean value of $38.7 \mathrm{ppbv}$. The temperature profile which is also depicted in Figure $7 \mathrm{c}$ shows clearly that the low $\mathrm{CO}$ values are taken within the tropopause. This is also supported by on board ozone measurements (Marenco, 1996), where simultaneously a strong increase is observed. Decreasing CO mixing ratios from the troposphere to the stratosphere have also been observed by several other researchers (Seiler and Junge, 1969; Seiler and Warneck, 1972; Gaunter et al., 1979; Pratt et al., 1980; Seiler and Fishman, 1981; Hipskind et al., 1987; Marenco et al., 1989). They report CO mixing ratios in the tropopause and lower 


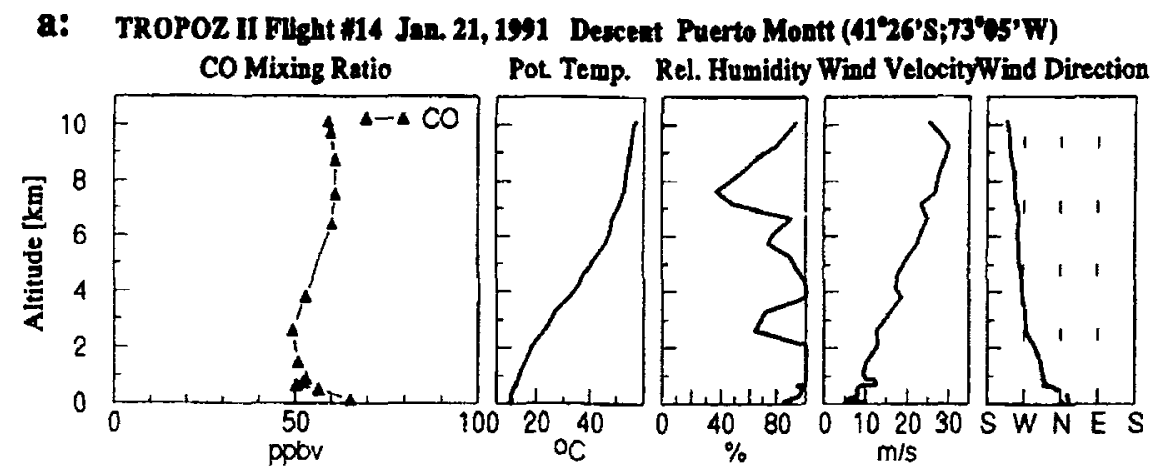

b: TROPOZ II Fught *15 Jax. 21, 1991 Ascent Puerto Montt (41'26'S;73'05'W)
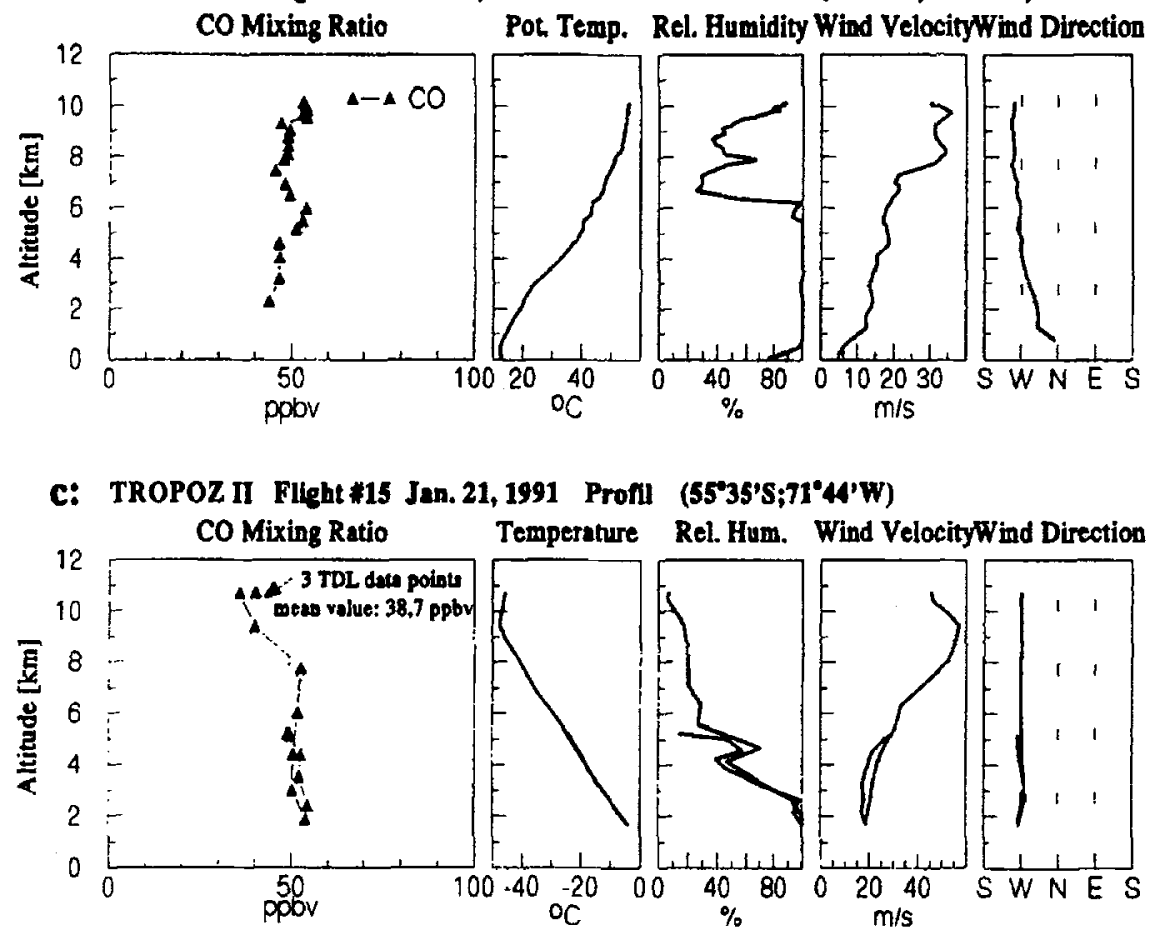

Figure 7. Same as Figure 2 but for (a) approaching Puerto Montt (landing 15h03 UT, $11 \mathrm{~h} 03$ local time), (b) ascent form Puerto Montt (take-off 17h09 UT, 13h09 local time), and (c) a profile at $55^{\circ} 35^{\prime} \mathrm{S} ; 71^{\circ} 44^{\prime} \mathrm{W}$ (here the temperature instead of the potential temperature is depicted).

stratosphere between $35 \mathrm{ppbv}$ and $65 \mathrm{ppbv}$, which is in good agreement with the values reported here.

\subsection{MEASUREMENTS BETWEEN $30^{\circ} \mathrm{S}$ AND $5^{\circ} \mathrm{N}$}

A very unexpected vertical profile, which is depicted in Figure 5a, is obtained during the descent to Lima $\left(12^{\circ} \mathrm{S}\right)$. In the middle troposphere low $\mathrm{CO}$ mixing ratios between 50 and $60 \mathrm{ppbv}$ are measured. Above $8 \mathrm{~km}$ altitude a sharp increase in the $\mathrm{CO}$ mixing ratio to values of $120 \mathrm{ppbv}$ is observed. This increase is correlated with an increase in relative humidity, which is also depicted in Figure 5a. Below 


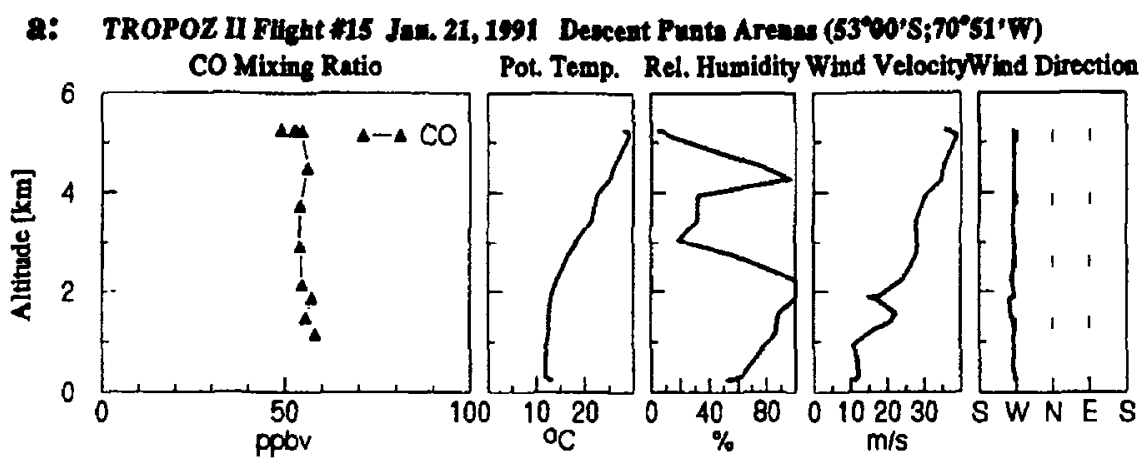

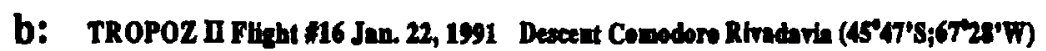

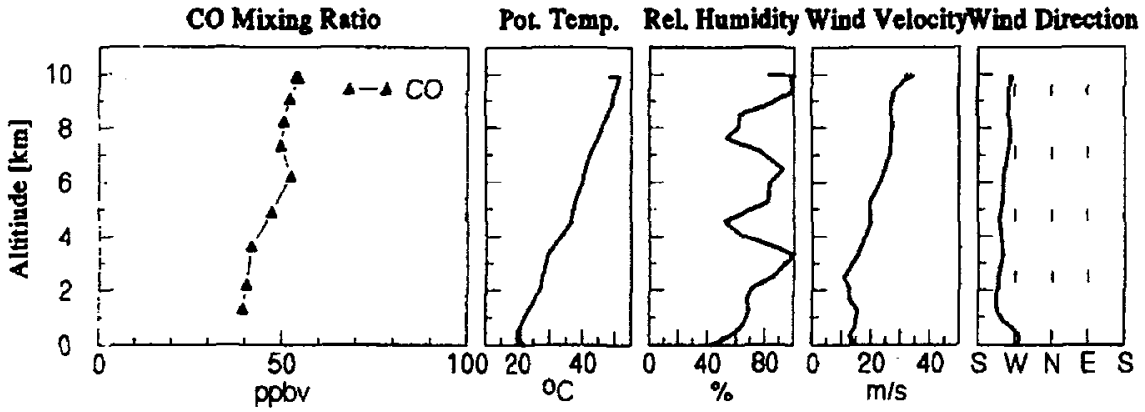

C: TROPOZ II Flight * 17 Jan. 22, 1991 Descent Buenos Aires (34'48'S;58³2'W)

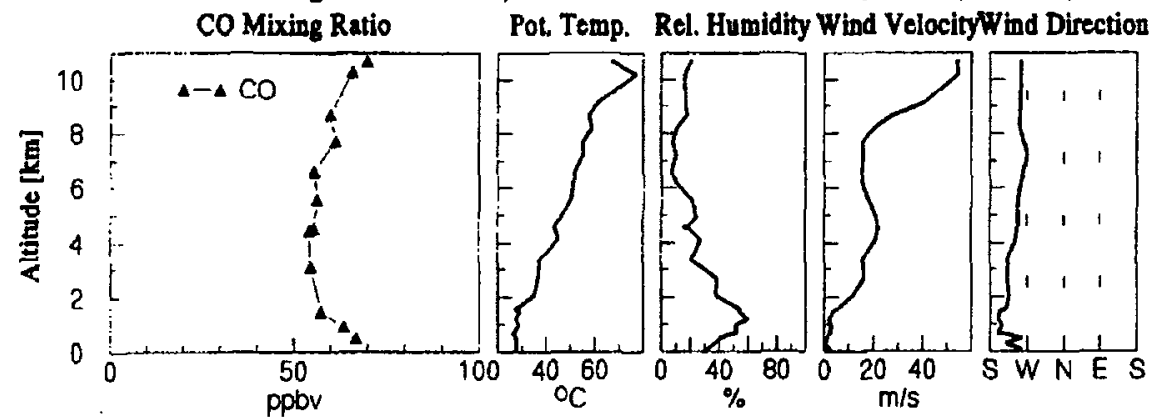

Figure 8. Same as Figure 2 but for (a) approaching Punta Arenas (landing 20h28 UT, 17h28 local time), (b) approaching Comodoro Rivadavia (landing 14h06 UT, 11 h06 local time), and (c) approaching Buenos Aires (landing $18 \mathrm{~h} 41 \mathrm{UT}, 15 \mathrm{~h} 41$ local time).

$2 \mathrm{~km}$ altitude the $\mathrm{CO}$ mixing ratio increases again, which can be attributed to anthropogenic pollution in the vicinity of Lima. Figures $5 b, 5 c$, and $6 a$, where additional $C O$ profiles near Lima and Antofagasta are depicted, show very similar features. In the middle troposphere very low $\mathrm{CO}$ mixing ratios (between 50 and $70 \mathrm{ppbv}$ ) are measured and at various altitudes sharp transitions to higher values at higher altitudes are found. The profiles obtained near Cali $\left(3^{\circ} \mathrm{N}\right)$ and Guayaquil $\left(2^{\circ} \mathrm{S}\right.$ ) (Figures $3 \mathrm{c}-4 \mathrm{c}$ ) have similar structures. The mixing ratios of $\mathrm{CO}$ in the middle troposphere are between 60 and $80 \mathrm{ppbv}$ and an increase to values of $100-120 \mathrm{ppbv}$ at cruising altitude is clearly resolved. The high mixing ratios at low altitude is again the result of anthropogenic pollution in the vicinity of the airports, which are 


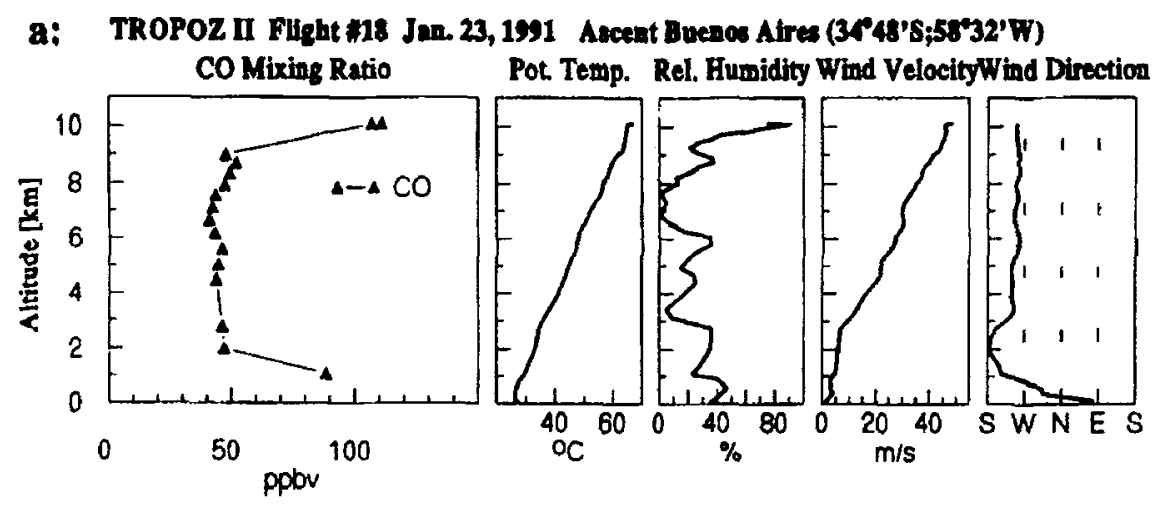

b: TROP0Z II Fught \$18 Jan. 23, 1991 Descent Porto Alegre (30'00'S;51'10'W)
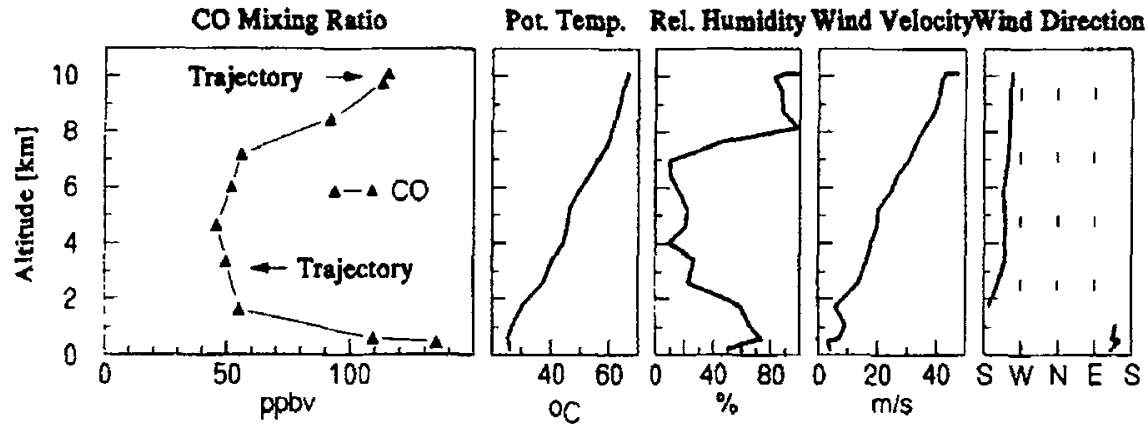

C: TROPOZ II Flight \#19 Jan. 23, 1991 Deacent Rlo de Janeiro (22 48'S; $43^{\circ} 15^{\prime}$ W)

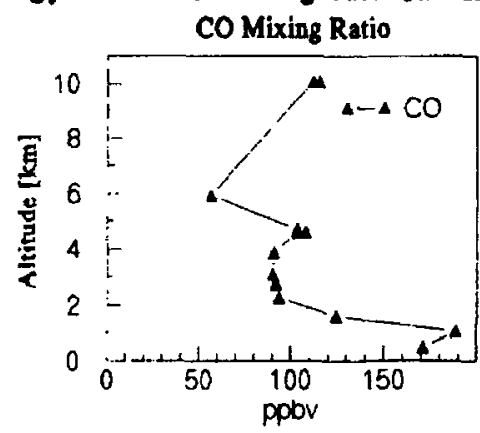
Pot. Temp. Rel. Humidity Wind VelocityWind Direction
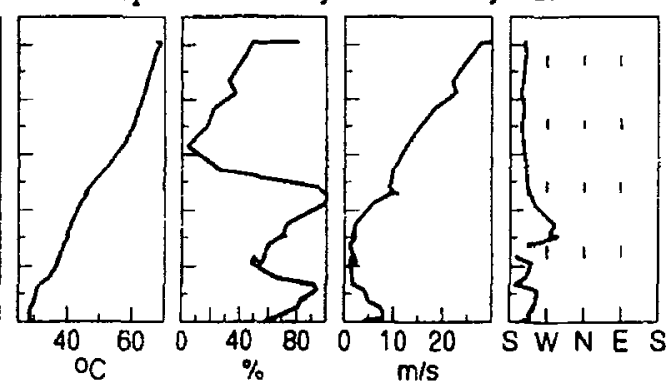

Figure 9. Same as Figure 2 but for (a) ascent form Buenos Aires (take-off 13h49 UT, 10h49 local time), (b) approaching Porto Alegre (landing $15 \mathrm{~h} 10$ UT, 12h10 local time), and (c) approaching Rio de Janeiro (landing $19 \mathrm{~h} 03 \mathrm{UT}, 16 \mathrm{h03}$ local time).

located at the outskirts of populated cities. The profiles discussed up to now are all taken near the west coast of South America. Figures $9 a, 9 b$ and $9 \mathrm{c}$ show the profiles measured during flights \#18 and \#19 near the east coast of South America. They also have a similar structure with low $\mathrm{CO}$ mixing ratios and low relative humidity in the middle troposphere and high $\mathrm{CO}$ mixing ratios in air masses with higher relative humidity at higher altitudes. Thus, measurements made between $5^{\circ} \mathrm{N}$ and $30^{\circ} \mathrm{S}$ on both sides of the South American continent show that airmasses with low $\mathrm{CO}$ concentrations $(50-80 \mathrm{ppbv})$ in the middle troposphere are overlaid by $\mathrm{CO}$ rich airmasses (100-120 ppbv) in the upper troposphere. These measurements are taken over a period of nine days, showing that the observed feature has both 


\section{a: TROPOZ II Filght "20 Jan. 25, 1991 Descent Salvador (1255'S;38'19'W)}

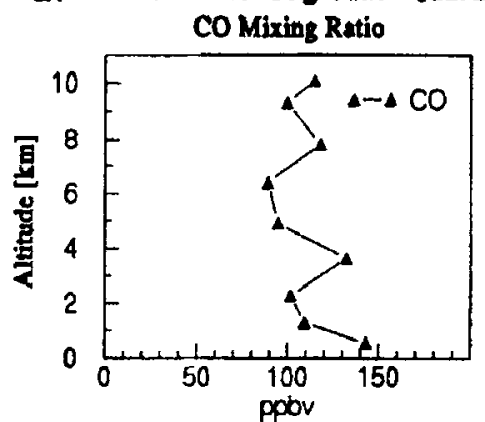

Pot. Temp. Rel. Humidity Wind VelocityWind Direction
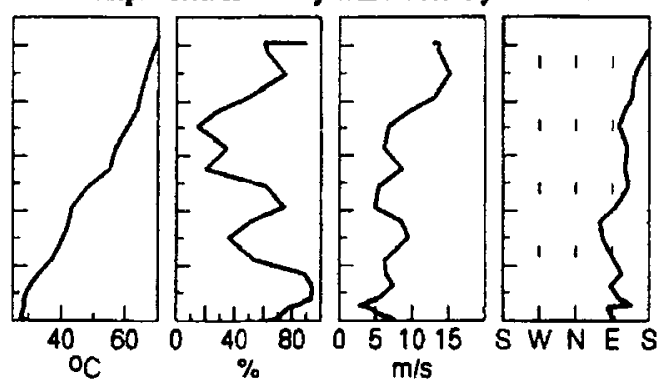

b: TROPOZ II Flleght *21 Jan. 25,1991 Arcent Selvador (12'55'S;38'19'W)

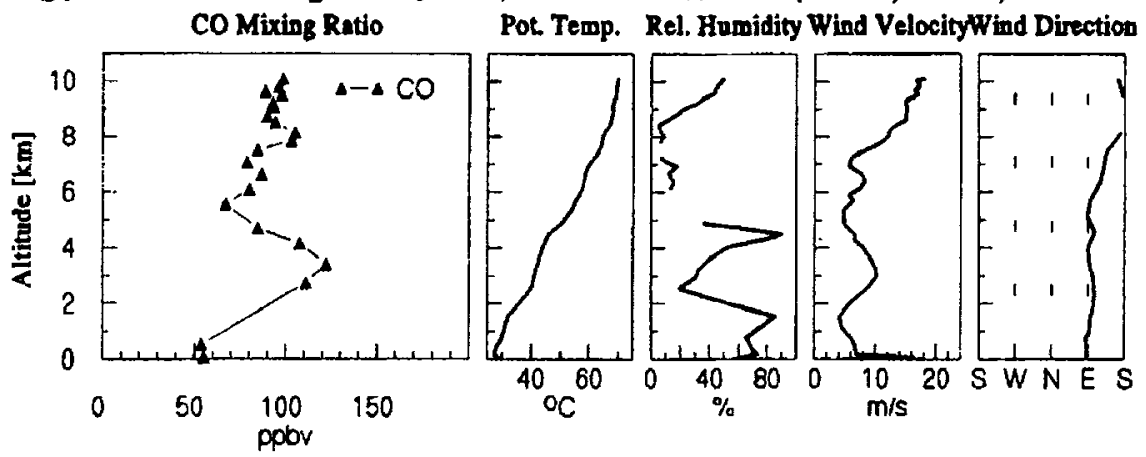

C: TROPOZ II Flight 21 Jan. 25, 1991 Deacent Fortaleza (03\%47'S;38³2'W)

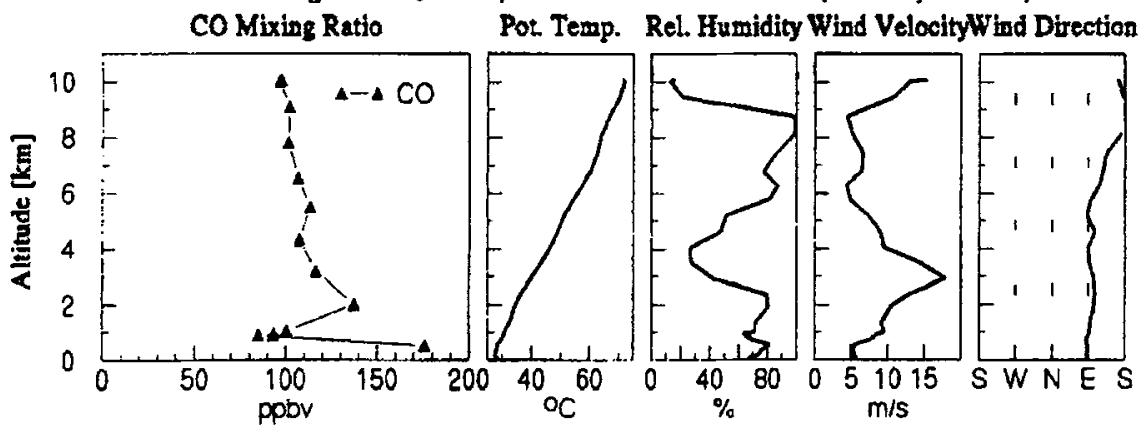

Figure 10. Same as Figure 2 but for (a) approaching Salvador (landing 15h $12 \mathrm{UT}, 12 \mathrm{~h} 12$ local time), (b) ascent from Salvador (take-off $16 \mathrm{~h} 32$ UT, 13h32 local time), and (c) approaching Fortaleza (landing $18 \mathrm{~h} 22 \mathrm{UT}, 15 \mathrm{~h} 22$ local time).

a long temporal and spatial persistence, suggesting that the $\mathrm{CO}$ rich airmasses at high altitudes are not an accidental feature but a mesoscale phenomenon which can probably be regarded as typical for this time of the year.

Earlier aircraft-based $\mathrm{CO}$ measurements performed in the vicinity of the South American coastlines by Seiler and Fishman (1981) in July/August 1974 and by Marenco et al. (1989) in June 1984 revealed no similar structure. Marenco et al. (1989) reports $\mathrm{CO}$ mixing ratios between 70 and $90 \mathrm{ppbv}$ in the region with no strong vertical structure and with a meridional gradient from north to south which is almost constant over the full tropospheric height. 

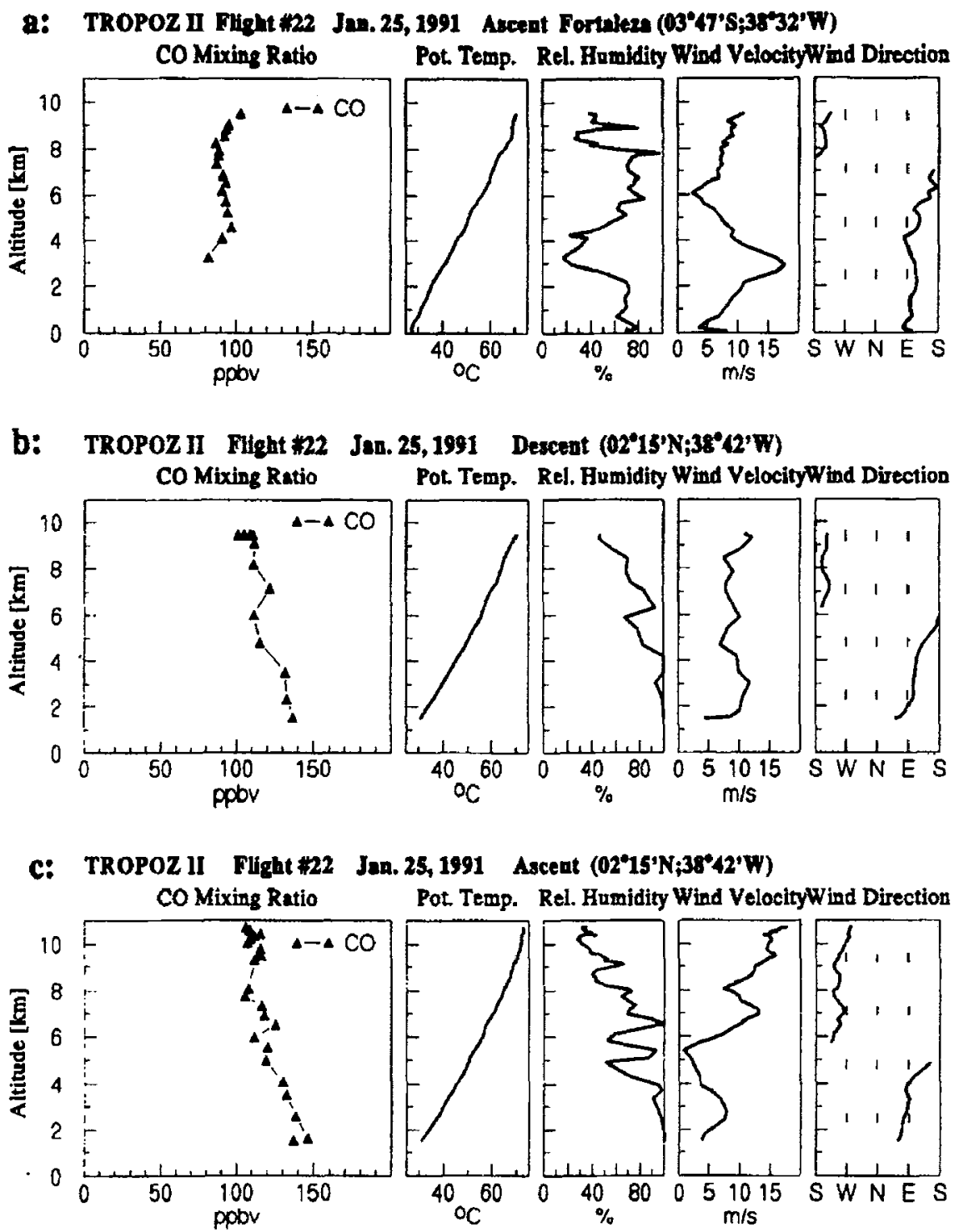

Figure 11. Same as Figure 2 but for (a) ascent form Fortaleza (take-off 20h 16 UT, $17 \mathrm{~h} 16$ local time), and an intermediate profile near $2^{\circ} 15^{\prime} \mathrm{N} ; 38^{\circ} 42^{\prime} \mathrm{W}((\mathrm{b})$ descent and (c) ascent).

Trajectory calculations performed with the help of Wolz (1991) in cooperation with the ECMWF give some indications about the origin of the $\mathrm{CO}$ rich airmasses found at high altitudes. Figure 20 depicts the three day backward isobaric trajectory of the air parcel sampled during flight $\# 9\left(4.5^{\circ} \mathrm{N} ; 76^{\circ} \mathrm{W}\right)$ at $10 \mathrm{~km}(250 \mathrm{hPa})$ altitude which has a CO mixing ratio of $120 \mathrm{ppbv}$ (see also Figure $3 \mathrm{c}$ ). The calculation shows that three day earlier, this airmass was located over central Amazonia. In contrast, the air parcel probed during the flight \#9 descent at $5.5 \mathrm{~km}(500 \mathrm{hPa})$ altitude (CO mixing ratio of $80 \mathrm{ppbv}$ ) has a completely different origin. It was transported a short distance from the north-west, as depicted in Figure 20. Figure 21 shows the trajectories of two air parcels measured during the descent to Lima (flight \#11, see also Figure 5a). The $\mathrm{CO}$ rich airmass at high altitude again has its origin over 


\section{a: TROPOZ II Fight 22 Jan. 25, 1991 Descent Recte (esecs'S;3453'W)}

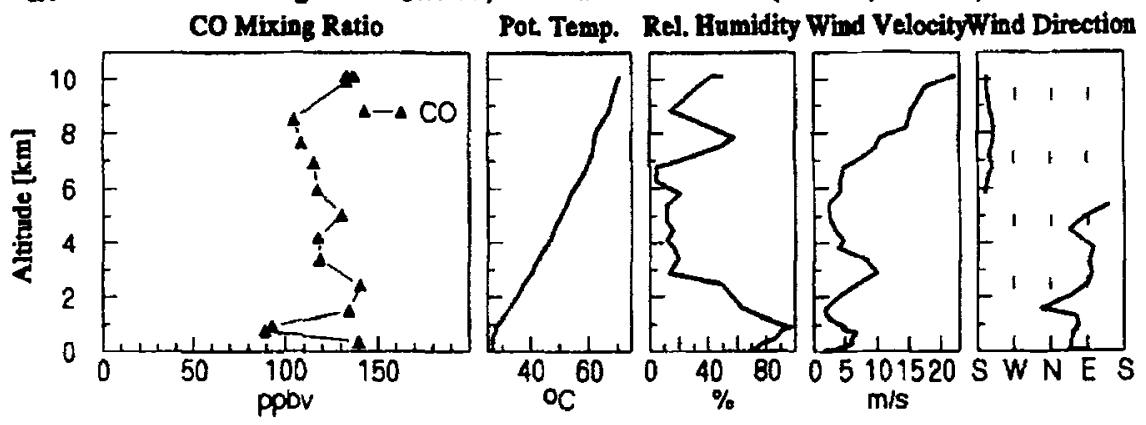

b: TROPOZ II Fllegt \$25 Jan. 29, 1991 Ascent Abidjan (05'15'N;03'53'W)

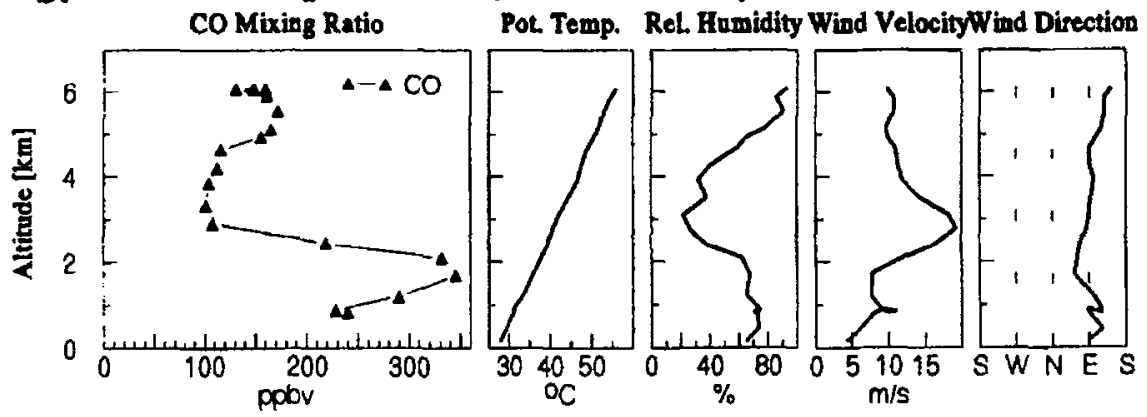

c: TROPOZ II Flight *25 Jan. 29, 1991 Descent (0745'N;05*4'W)

CO Mixing Ratio

Pot. Temp. Rel. Humidity Wind VelocityWind Direction

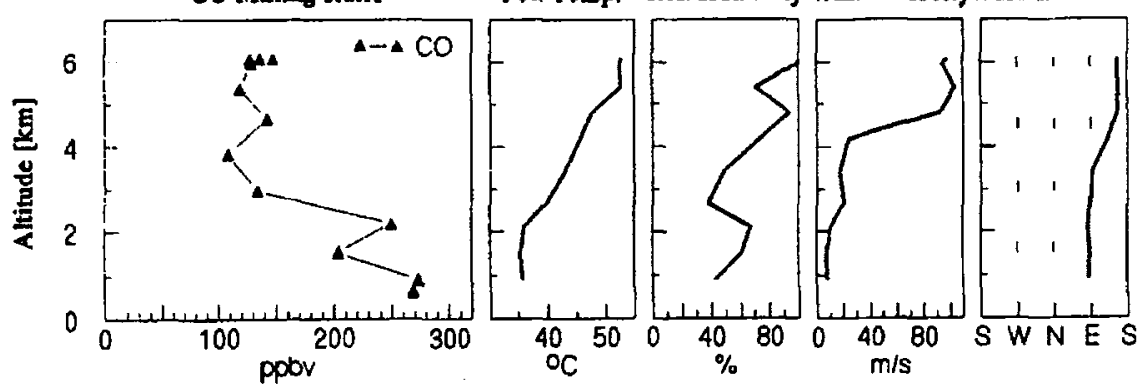

Figure 12. Same as Figure 2 but for (a) approaching Recife (landing 23h39 UT, 17h16 local time), (b) ascent from Abidjan (take-off $15 \mathrm{~h} 06 \mathrm{UT}=\mathrm{local}$ time), and (c) descent near $7^{\circ} 45^{\prime} \mathrm{N}$; $5^{\circ} 4^{\prime} \mathrm{W}$.

central South America but the air parcel probed at $5.5 \mathrm{~km}$ altitude came over the Pacific. Figure 23 illustrates the trajectories of air parcels measured near the east coast of South America during flight \#18 (see also Figure 9b). Three days earlier, the air parcel probed at $10 \mathrm{~km}$ altitude was located over central South America, first moving westwards before being transported very rapidly eastwards by the subtropical jet stream. The air parcel measured at $3 \mathrm{~km}$ altitude has its origin at higher southern latitudes. These examples as well as further trajectory calculations (not depicted here) show that all of the $\mathrm{CO}$ rich airmasses found aloft can be traced back to central South America. Central South America is a region of very strong convection and it is likely that the $\mathrm{CO}$ rich airmasses were transported rapidly 


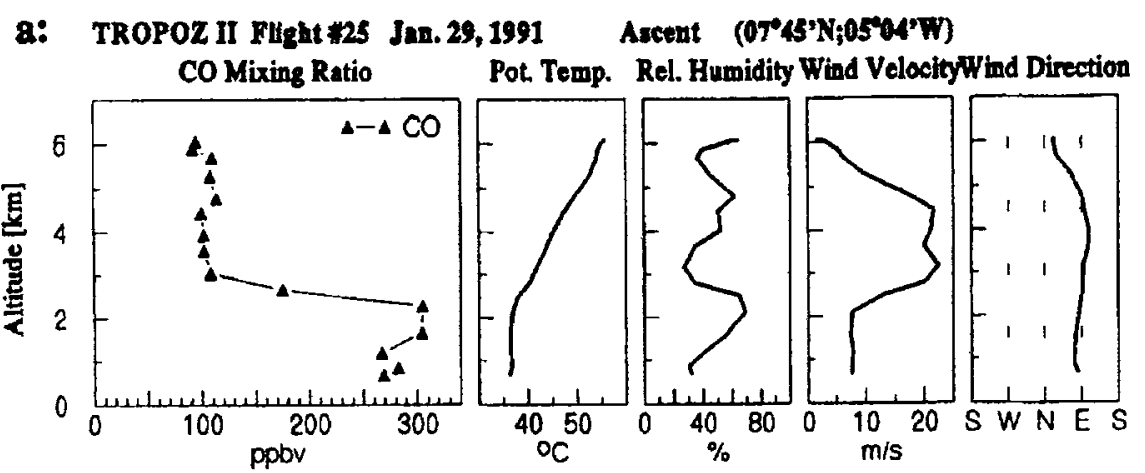

b: TROPOZ II Flight *25 Jne. 29, 1991 Descent (09'32'N;0733'W)

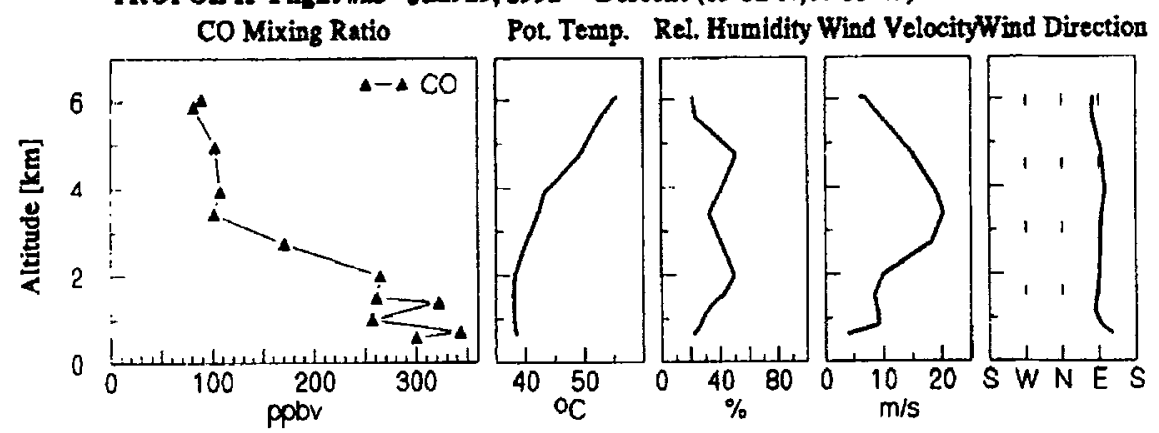

c: TROPOZ II Flight $\$ 25$ Jan. 29, 1991 Ascent (09'32'N;0T33'W)

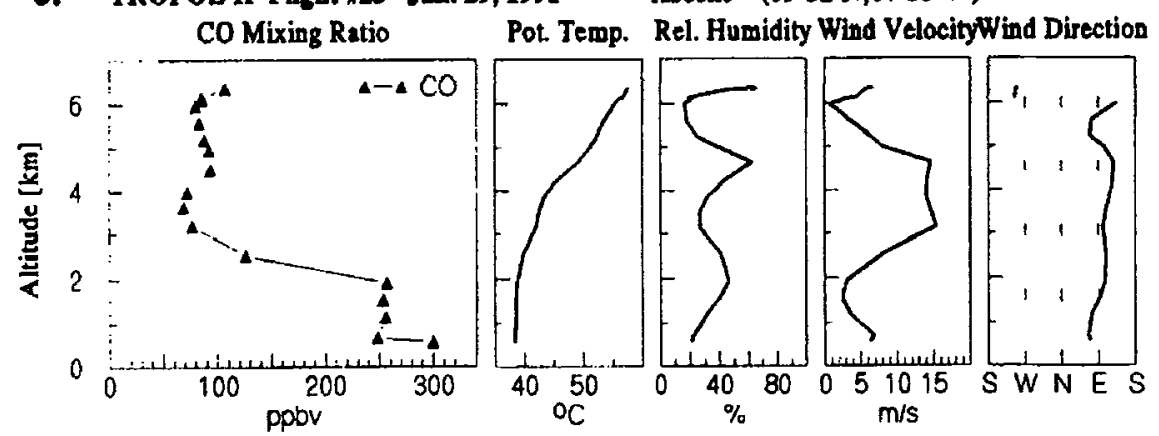

Figure 13. Same as Figure 2 but for (a) ascent near $7^{\circ} 45^{\prime} \mathrm{N} ; 5^{\circ} 04^{\prime} \mathrm{W}$, and a profile near $9^{\circ} 32^{\prime} \mathrm{N}$; $7^{\circ} 33^{\prime} \mathrm{W}((\mathrm{b})$ descent and (c) ascent).

upward from the boundary layer and middle troposphere to high altitudes. The correlation between the $\mathrm{CO}$ increase at higher altitudes and the relative humidity supports this hypotheses (see Figures $3 c, 4 b-c, 5 a, 9 a-c$ ).

The database observed and available here is not complete enough to allow a clear identification of the $\mathrm{CO}$ source responsible for the $\mathrm{CO}$ rich airmasses. In the following several sources of $\mathrm{CO}$ will be briefly discussed. This will lead to some new aspects in the interpretation of the data presented here. Due to the low population density in South America $\mathrm{CO}$ emissions from anthropogenic activities are very unlikely to be the cause of the large scale $\mathrm{CO}$ enhancement. $\mathrm{CO}$ production by the Amazon rain forest during the wet season, which is from November to June, was studied during ABLE $2 \mathrm{~B}$, an intensive measurement campaign conducted in 


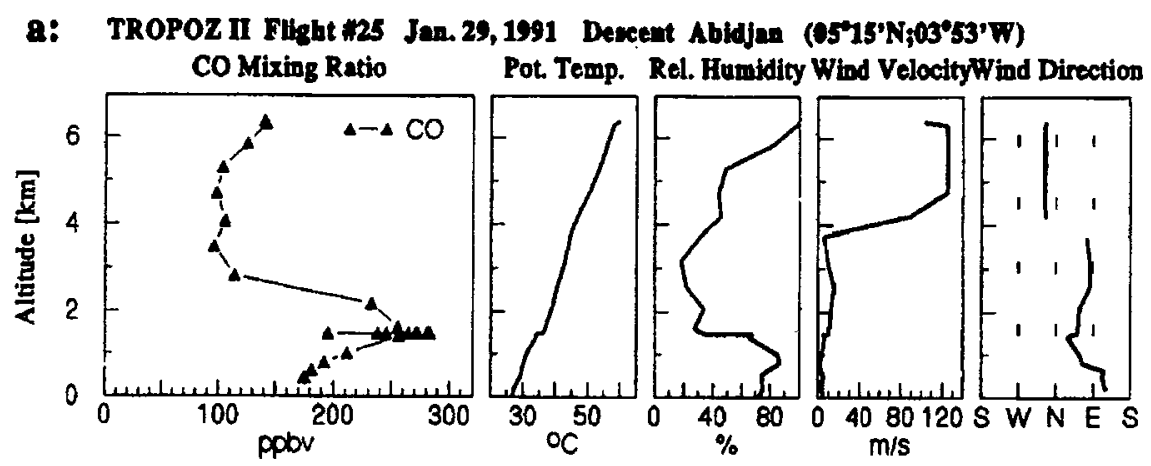

b: TROPOZ II Flight \#27 Jan. 31, 1991 Arcent Abidjen (05'15'N;03'53'W)

CO Mixing Ratio

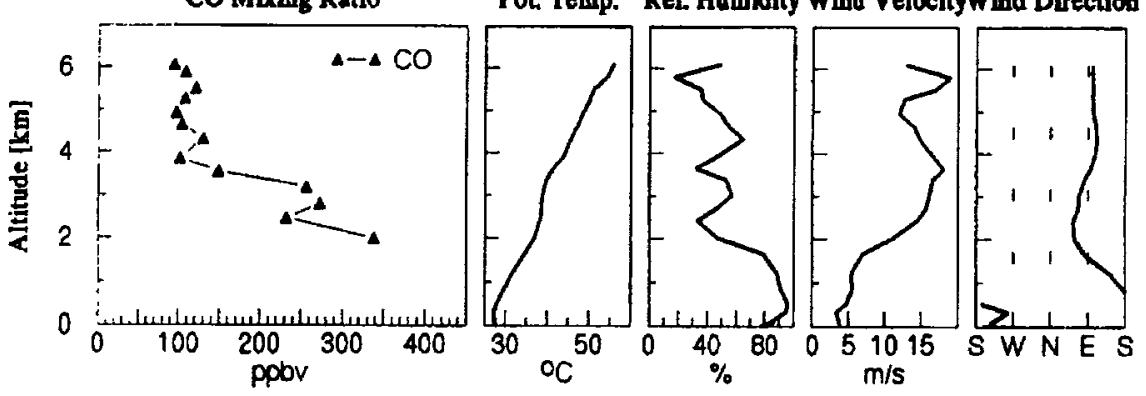

C: TROPOZ II Flight $\$ 27$ Jan. 31, 1991 Descent (0T04N;0023'W)

CO Mixing Ratio

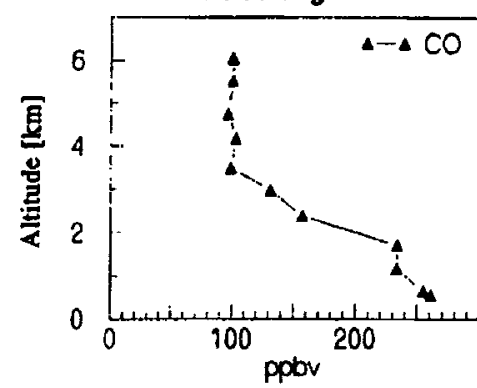

Pot. Temp. Rel. Humidity Wind VelocityWind Direction
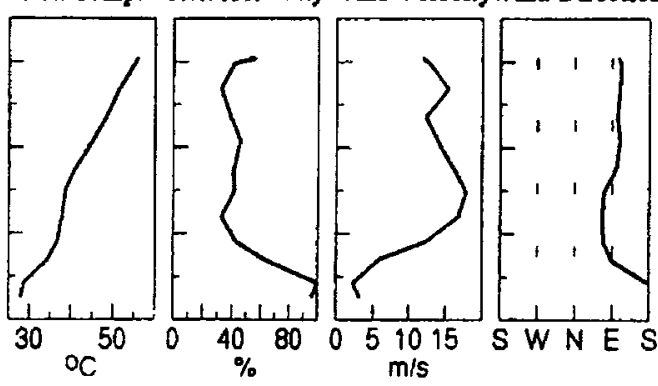

Figure 14. Same as Figure 2 but for (a) approaching Abidjan (landing 17h36 UT = local time), (b) ascent from Abidjan (take-off $9 \mathrm{~h} 32 \mathrm{UT}=$ local time), and (c) a descent near $7^{\circ} 04^{\prime} \mathrm{N}$; $6^{\circ} 23^{\prime} \mathrm{W}$.

April/May 1987 (Harriss et al., 1990a) in the Amazon region. Ground-based CO measurements in the vicinity of Manaus $\left(3^{\circ} \mathrm{S} ; 60^{\circ} \mathrm{W}\right)$, revealed a mean $\mathrm{CO}$ mixing ratio of 102.9 $\pm 11.4 \mathrm{ppbv}$ (Kirchhoff and Marinho, 1990): Harriss et al. (1990b) report airborne $\mathrm{CO}$ measurements over central Amazonia which show $\mathrm{CO}$ mixing ratios of about $100 \mathrm{ppbv}$ within the boundary layer and about $80 \mathrm{ppbv}$ in the lower troposphere. Compared to the measurements reported here, where $\mathrm{CO}$ mixing ratios between 100 and $120 \mathrm{ppbv}$ were found at 8 to $10 \mathrm{~km}$ altitude, the ABLE 2B data indicate that the $\mathrm{CO}$ source strength of the rain forest is probably not strong enough to be the origin of the $\mathrm{CO}$ rich airmass found in this study. A further strong source of carbon monoxide is biomass burning, which predominantly takes place during the 


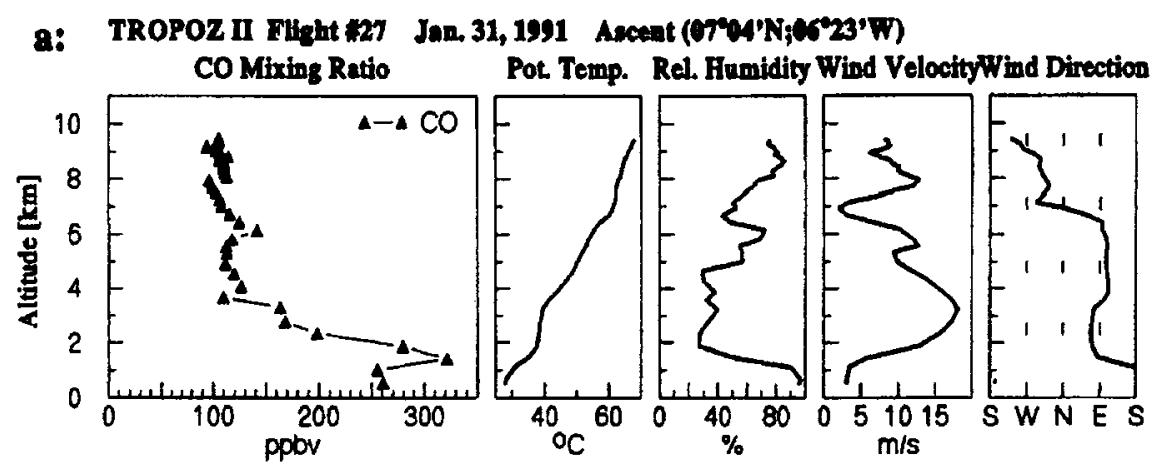

b: TROPOZ II Pight 227 Jan. 31, 1991 Deacent Dakar (164'N;1728'W)

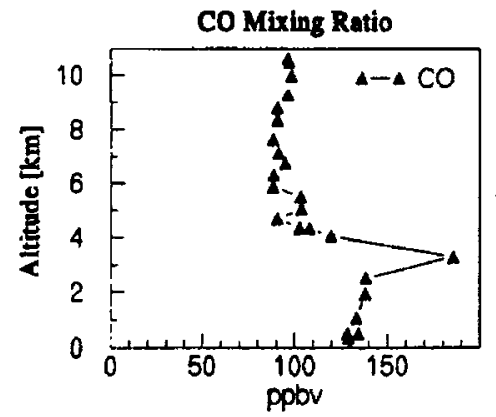

Pot. Temp. Rel. Humidity Wind Velocity Wind Direction
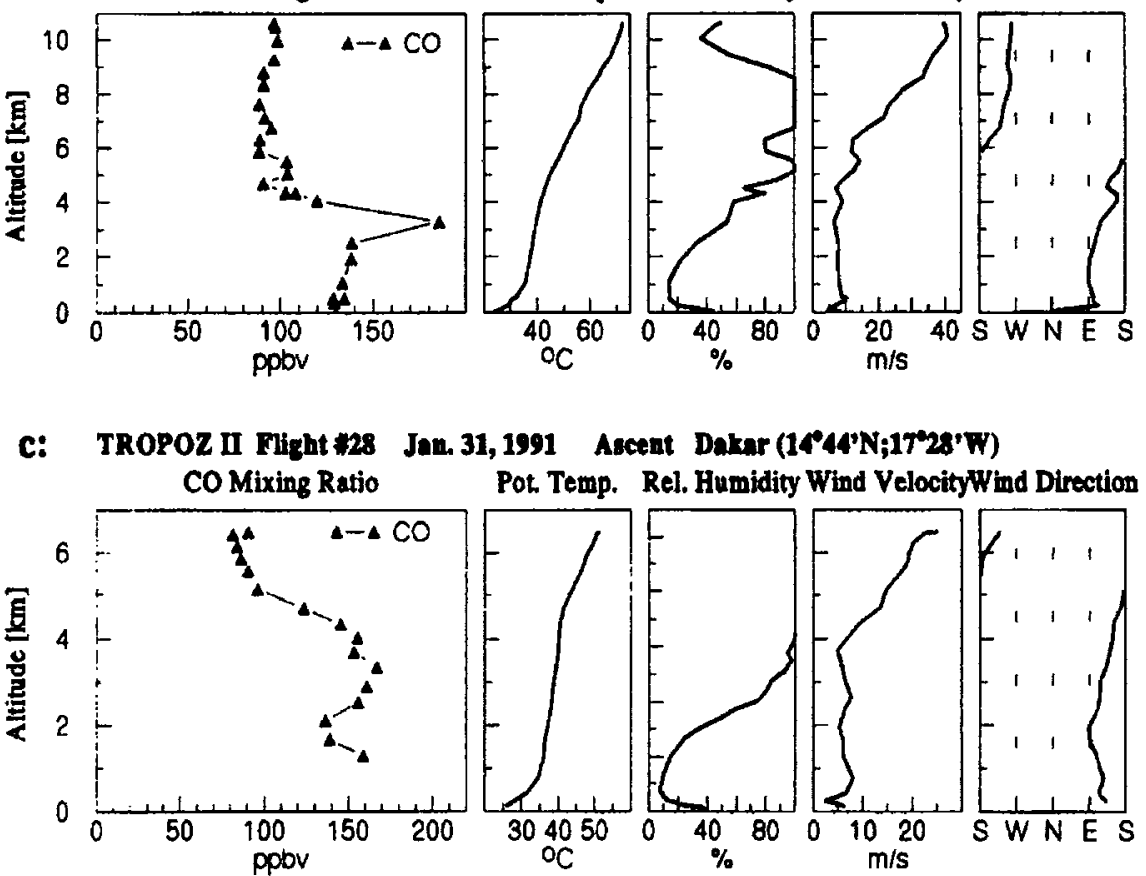

Figure 15. Same as Figure 2 but for (a) ascent near $7^{\circ} 04^{\prime} \mathrm{N} ; 6^{\circ} 23^{\prime} \mathrm{W}$, (b) approaching Dakar (landing 12h43 UT - local time), and (c) ascent from Dakar (take-off 14h31 UT = local time).

dry season, between July and September in the Southern Hemisphere. In January biomass burning activities with a large impact on tropospheric $\mathrm{CO}$ mixing ratios are reported for Northern Hemispheric savanna regions such as the Venezuelan savanna $\left(6^{\circ} \mathrm{N}-10^{\circ} \mathrm{N}\right)$ (Sanhueza, 1991) and for the West African savanna, as described in the next section. Global circulation studies (Molion, 1987) show that in January the middle troposphere over central South America is likely to be under the influence of Northern Hemispheric airmasses. This leads to the conclusion that airmasses influenced by biomass burning from Northern Hemispheric savanna regions are transported within the middle and lower troposphere to central South America. There they are subjected to a rapid vertical motion which is driven by convection. At higher altitudes $(8-10 \mathrm{~km})$ the $\mathrm{CO}$ rich airmasses are partly transported to 


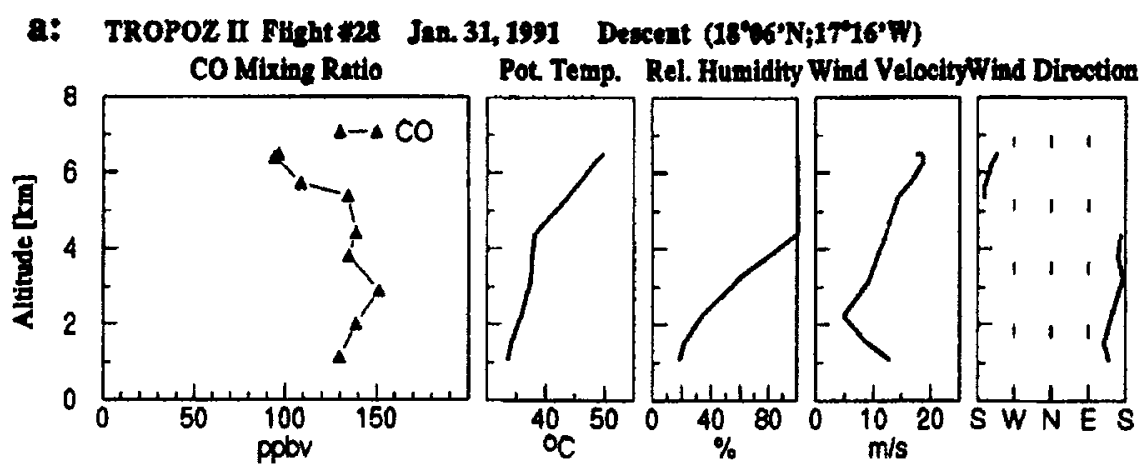

b: TROPOZ II Filght tos Jne 31, 1991 Ascent (1606'N;17'16' W')

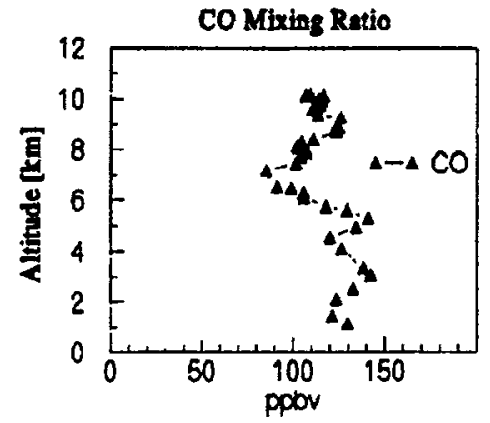

Pot. Temp. Rel. Humidity Wind Velocity Wind Direction

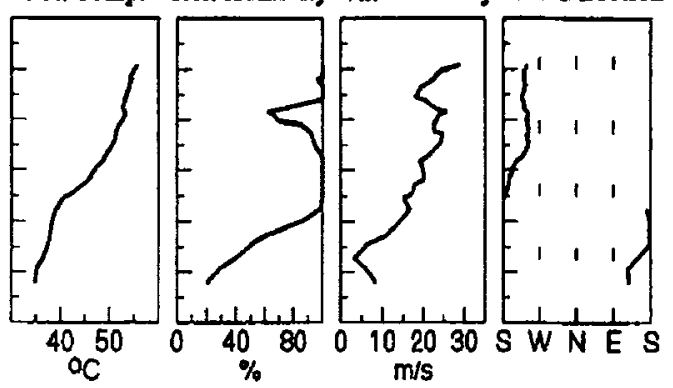

C: TROPOZ II Fleht 28 Jan. 31, 1991 Deacent Las Palmas (2T56'N;15222W)

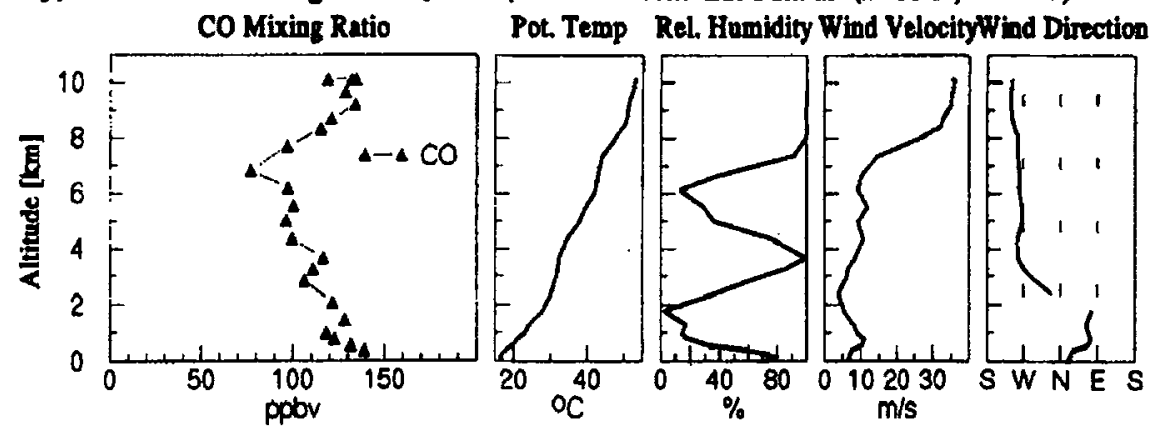

Figure 16. Same as Figure 2 but for a profile near $18^{\circ} 06^{\prime} \mathrm{N} ; 17^{\circ} 16^{\prime} \mathrm{W}$ ((a) descent, (b) ascent), and (c) approaching Las Palmas (landing 16h59 UT = local time).

higher southern latitudes, creating a sharp airmass boundary (in the sense of the $\mathrm{CO}$ content) with the $\mathrm{CO}$ poor air found south of $30^{\circ} \mathrm{S}$. Our hypotheses thus relates to three phenomena occurring in January:

(1) biomass burning with strong $\mathrm{CO}$ emissions in the Northern Hemispheric savanna regions;

(2) long-range transport of Northern Hemispheric air to central South America;

(3) strong convection over central South America.

This interpretation of the $\mathrm{CO}$ data presented here implies that the influence of Northern Hemispheric biomass burning can be seen up to $30^{\circ} \mathrm{S}$ and that carbon monoxide can be regarded as a tracer to study an interhemispheric exchange mechanism. 
a: TROPOZ II Flight 229 Feb. 1, 1991 Ascent La Palmes (2T'5s'N;1522'W)

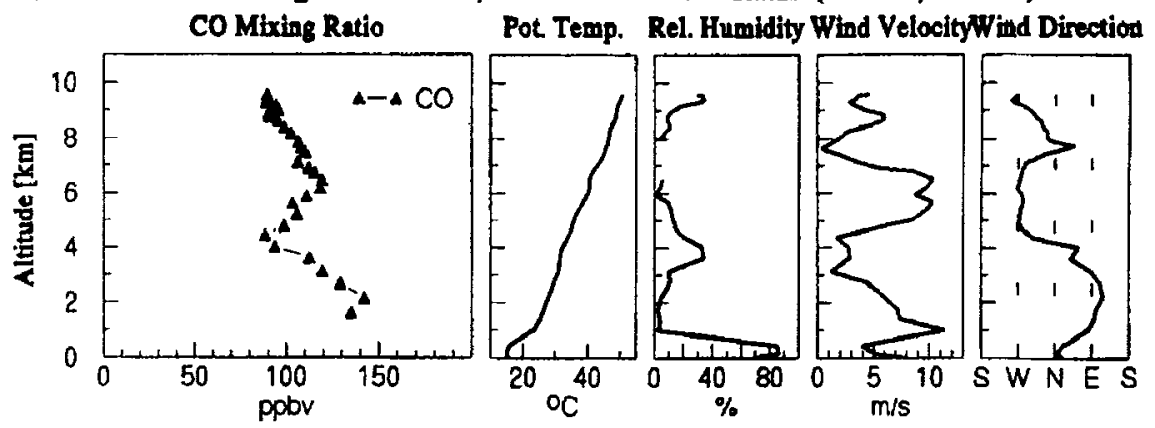

b: TROPOZ II Flight *29 Feb. 1, 1991 Descent Lbbon (3846'N;0907'W)

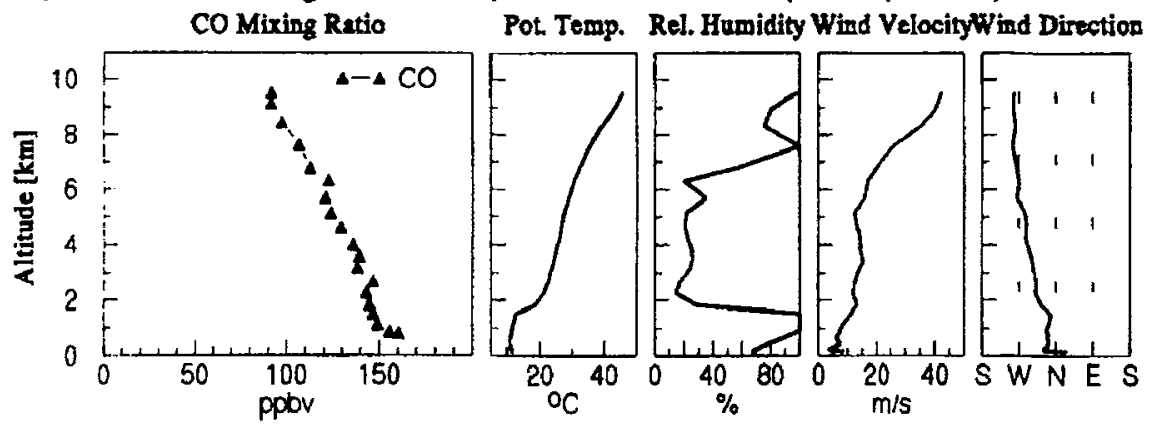

C: TROPOZ II Flight *30 Feb. 1, 1991 Descent Brétigny (48'35'N;02'19'E) CO Mixing Ratio Pot. Temp. Rel. Humidity Wind VelocityWind Direction

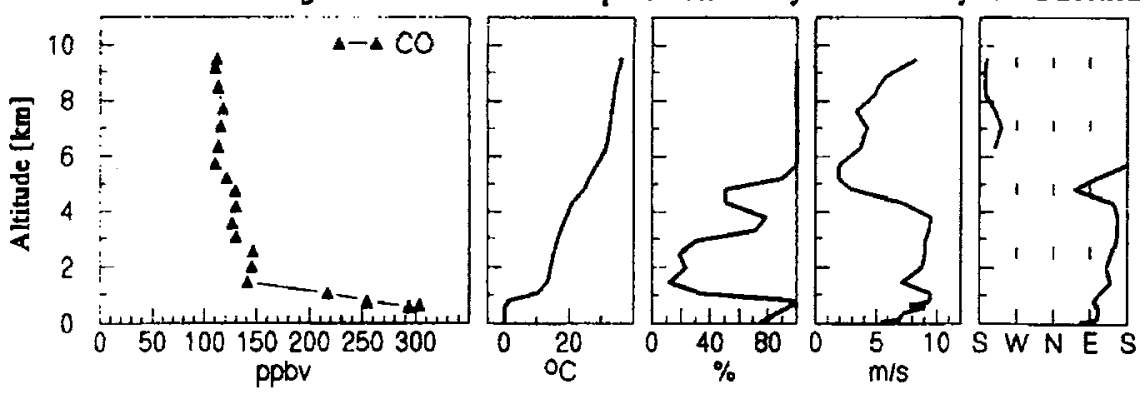

Figure 17. Same as Figure 2 but for (a) ascent from Las Palmas (take-off 10h25 UT $=$ local time), (b) approaching Lisbon (landing $12 \mathrm{~h} 31 \mathrm{UT}=$ local time), and (c) approaching Brétigny (landing 16h40 UT, 17h40 local time).

\subsection{FLIGHTS NEAR WEST AFRICA}

The vertical profiles obtained near West Africa i.e. flight \#25 (Abidjan-Abidjan, Figures 12b-14a), flight \#27 (Abidjan-Dakar, Figures 14b-15b) and the ascent from Dakar (flight \#28, Figure 15c) can be grouped together. They all show high $\mathrm{CO}$ mixing ratios in the range of $200-350 \mathrm{ppbv}$ in the lower troposphere. At 3-4 $\mathrm{km}$ altitude the $\mathrm{CO}$ mixing ratios decrease very rapidly to values of about $100 \mathrm{ppbv}$ and the mixing ratios are then constant up to the maximum cruising altitude. The flights were performed during the dry season of the West African savanna region, when intensive biomass burning was taking place. Menaut et al. (1991) estimate that about $227 \times 10^{6}$ ha of West African savanna are bumed and about $28 \times 10^{6}$ 


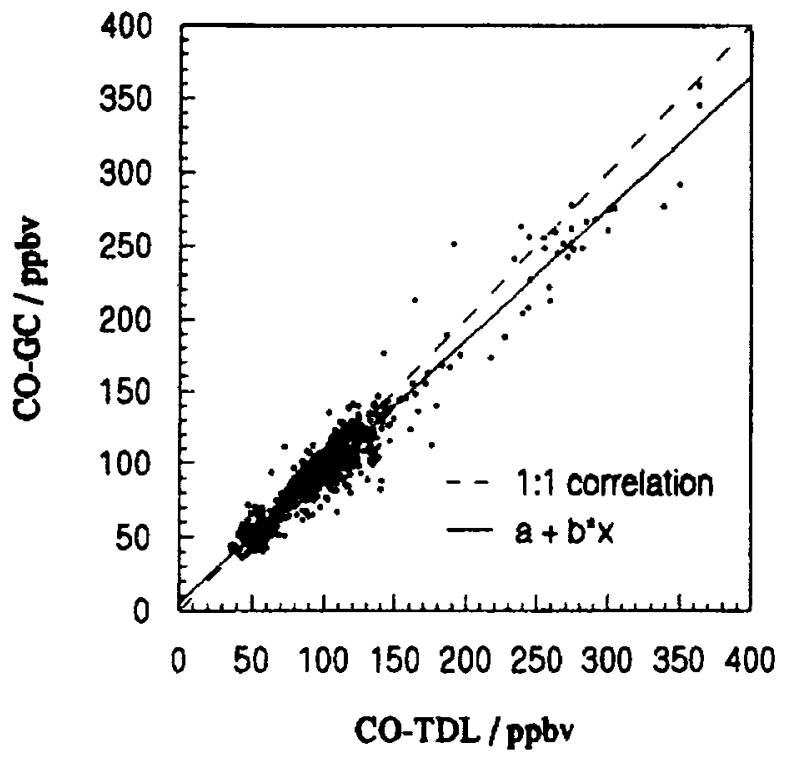

Figure 18. Airborne $\mathrm{CO}$ intercomparison between the tunable diode laser absorption spectroscopy (CO-TDL) and the gas-chromatography technique (CO-GC) (Marenco, 1996). All GC measurements performed during the sampling interval of the TDL-instrument (FLAIR) are averaged and are represented by a single dot in the figure. The solid line is a least-squares fit $(y=a+b x)$ to the data. The parameters of the fit are given in Table I. For reference, the identity $(y=x)$ is indicated by the broken line.

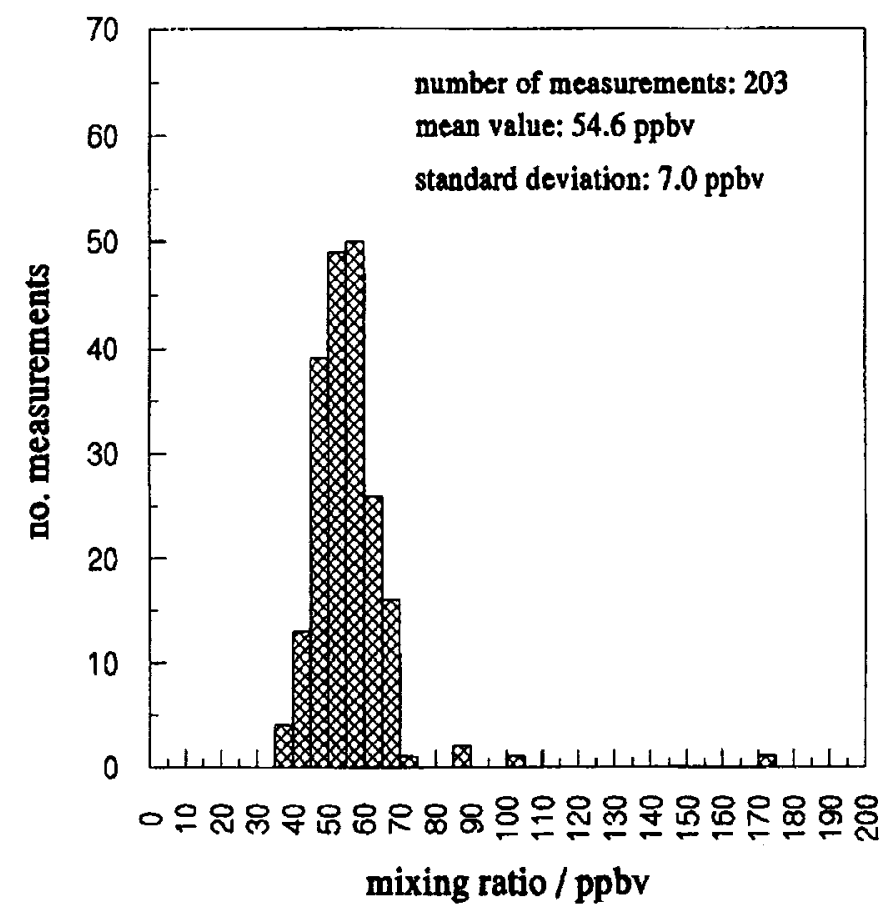

Figure 19. Histogram showing the distribution of all CO measurements made with the FLAIRinstrument south of $30^{\circ} \mathrm{S}$ during TROPOZ II. 
ECMWF 3-D BACKWARD ANALYSIS TRAJECTORIES INITIAL DATE: 1991-01-15-18UT

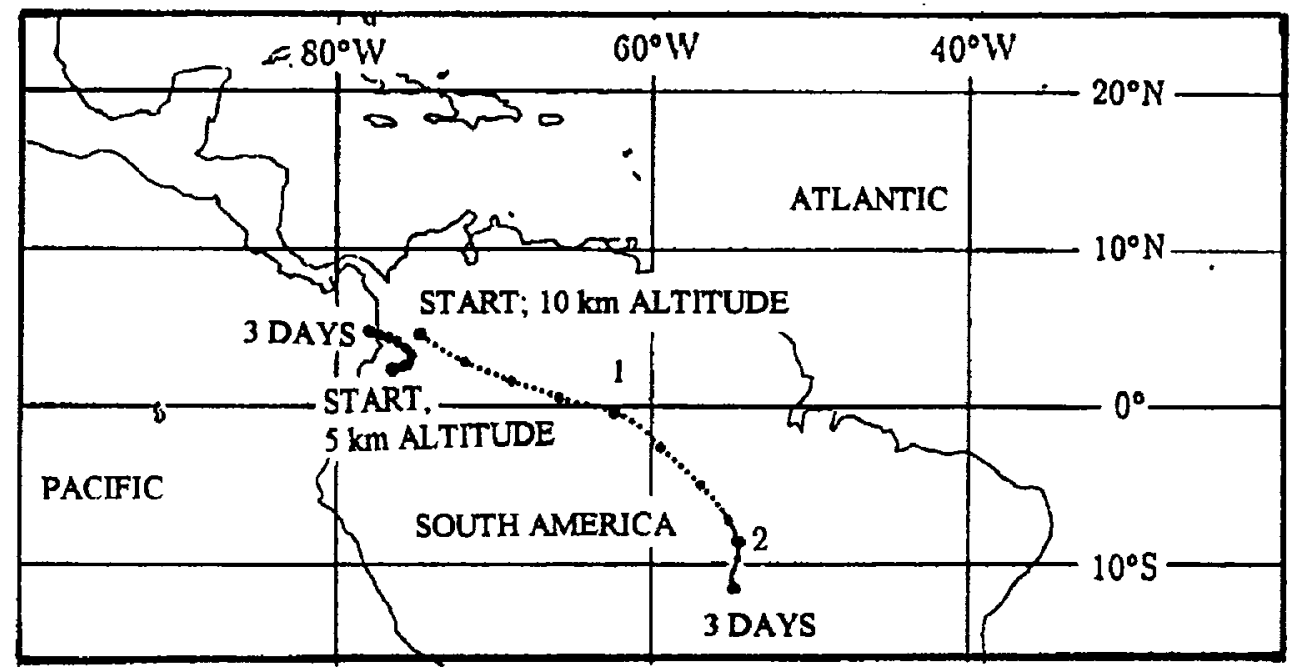

Figure 20. Three days backward calculation of the airmass sampled during flight \#9, (a) at $4.5^{\circ} \mathrm{N} ; 76^{\circ} \mathrm{W}, 10 \mathrm{~km}$ altitude $(250 \mathrm{hPa})$ and $(\mathrm{b})$ at $3.7^{\circ} \mathrm{N} ; 77^{\circ} \mathrm{W}, 5 \mathrm{~km}$ altitude $(500 \mathrm{hPa})$, see also Figure $3 \mathrm{c}$.

\section{ECNWF 3-D BACKWARD ANALYSIS TRAJECTORIES} INITIAL DATE: 1991-01-16-18UT

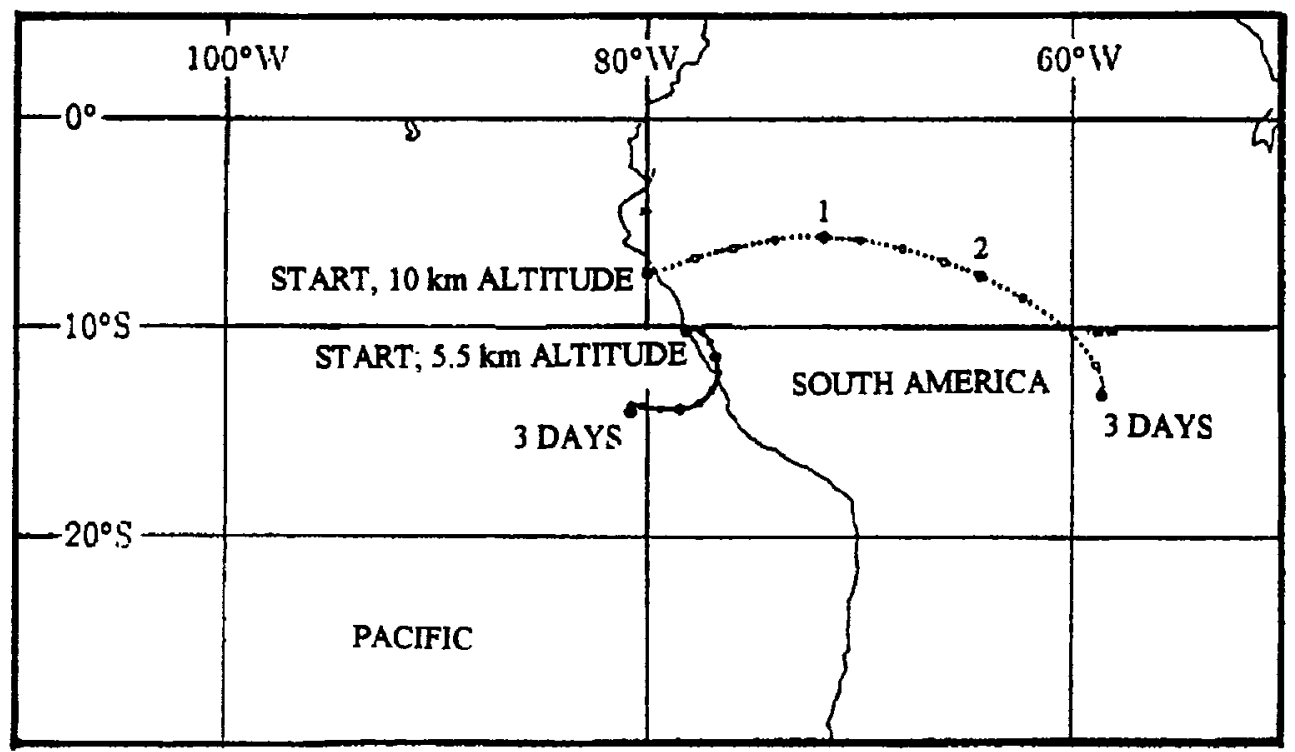

Figure 21. Three days backward calculation of the airmass sampled during flight \#11, (a) at $7^{\circ} \mathrm{S} ; 80^{\circ} \mathrm{W}, 10 \mathrm{~km}(200 \mathrm{hPa})$ altitude, and (b) $10^{\circ} \mathrm{S} ; 77^{\circ} \mathrm{W}, 5.5 \mathrm{~km}(500 \mathrm{hPa})$ altitude, see also Figure 5a.

of $\mathrm{CO}$ are emitted by this process every year during the dry season. Trajectory calculations show that the airmasses probed have passed regions in West Africa where biomass burning was taking place and also some burning activities were 


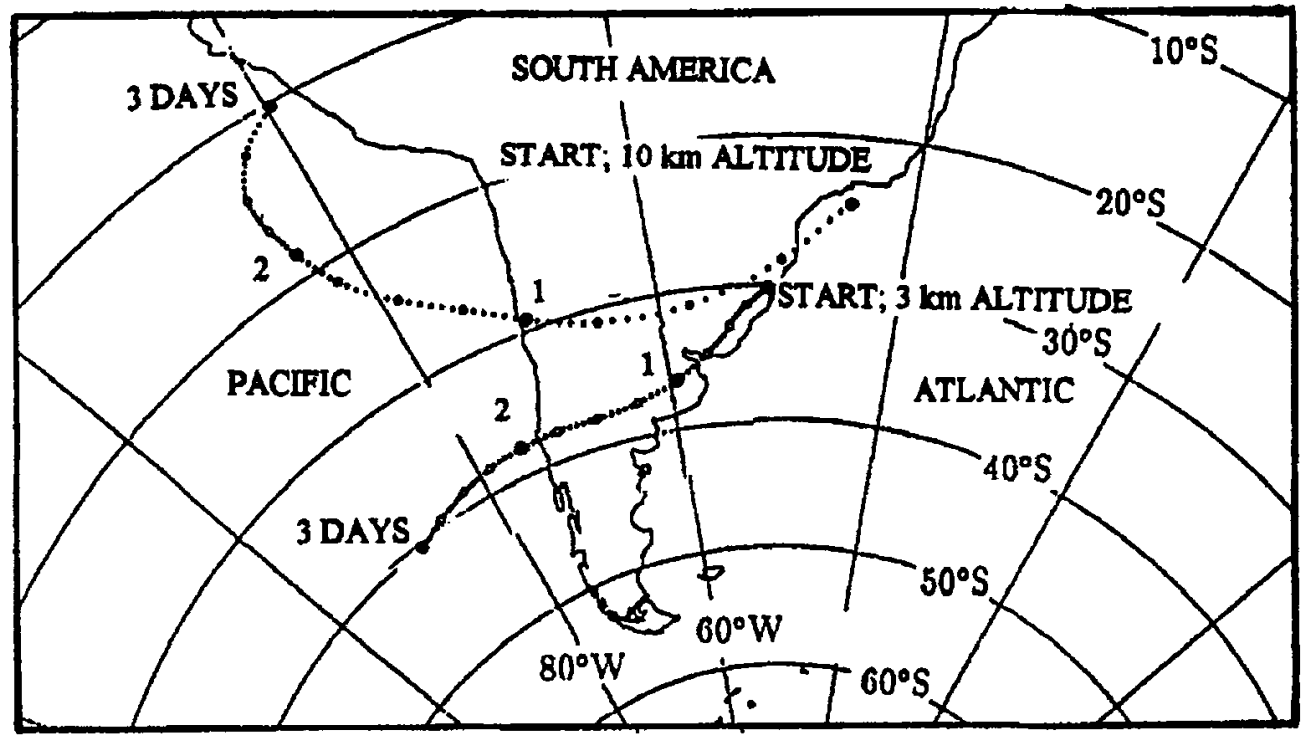

Figure 22. Three days backward calculation of the airmass sampled during flight \#18, (a) at $32^{\circ} \mathrm{S} ; 53^{\circ} \mathrm{W}, 10 \mathrm{~km}(200 \mathrm{hPa})$ altitude, and (b) $30^{\circ} \mathrm{S} ; 53^{\circ} \mathrm{W}, 3 \mathrm{~km}(700 \mathrm{hPa})$ altitude, see also Figure $9 \mathrm{~b}$.

visually observed when flying over Ivory Coast. Therefore, the high $\mathrm{CO}$ mixing ratios found in the lower troposphere can very likely be attributed to biomass burning. The measurements presented here show that the lower troposphere is strongly polluted on a large regional scale, spanning over 5 to 10 degrees latitude. As it can be seen from the potential temperature profiles, a labile stratification is present up to $3-4 \mathrm{~km}$ altitude, where the trade wind inversion is located. Under the trade wind inversion the pollutants are well mixed and vertical exchange to the middle troposphere is suppressed. CO mixing ratios of the order of $100 \mathrm{ppbv}$ found above the trade wind inversion are typical for Northern Hemispheric free tropospheric air (Seiler, 1974).

The profiles obtained on 29 January during take off and landing at Abidjan (Figures $12 \mathrm{~b}$ and $14 \mathrm{a}$ ) show a further significant feature. Maximum $\mathrm{CO}$ mixing ratios are found at about $1.5-2 \mathrm{~km}$ altitude and the $\mathrm{CO}$ mixing ratios decrease at lower altitudes. This shape is different to the profiles obtained further north over the Ivory Coast (Figures 12c-13c), where the $\mathrm{CO}$ mixing ratios within the boundary layer are nearly constant and no decrease below $2 \mathrm{~km}$ altitude is observed. The profiles flown near Abidjan cross the inter-tropical front (ITF). This airmass boundary is a typical structure of the inter-tropical convergence zone (ITCZ) in the region of the gulf of Guinea. The ITF is established when the moist south-east monsoon crosses the equator and meets the hot and dry Harmattan trade winds which have crossed the Sahara dessert and the savanna region from the north-west. The warmer continental airmasses slide upwards upon the Southern Hemispheric 
ECMWF 3-D BACKWARO ANALYSIS TRAJECTORIES

INITIAL OATE: 1991-01-11-18UT

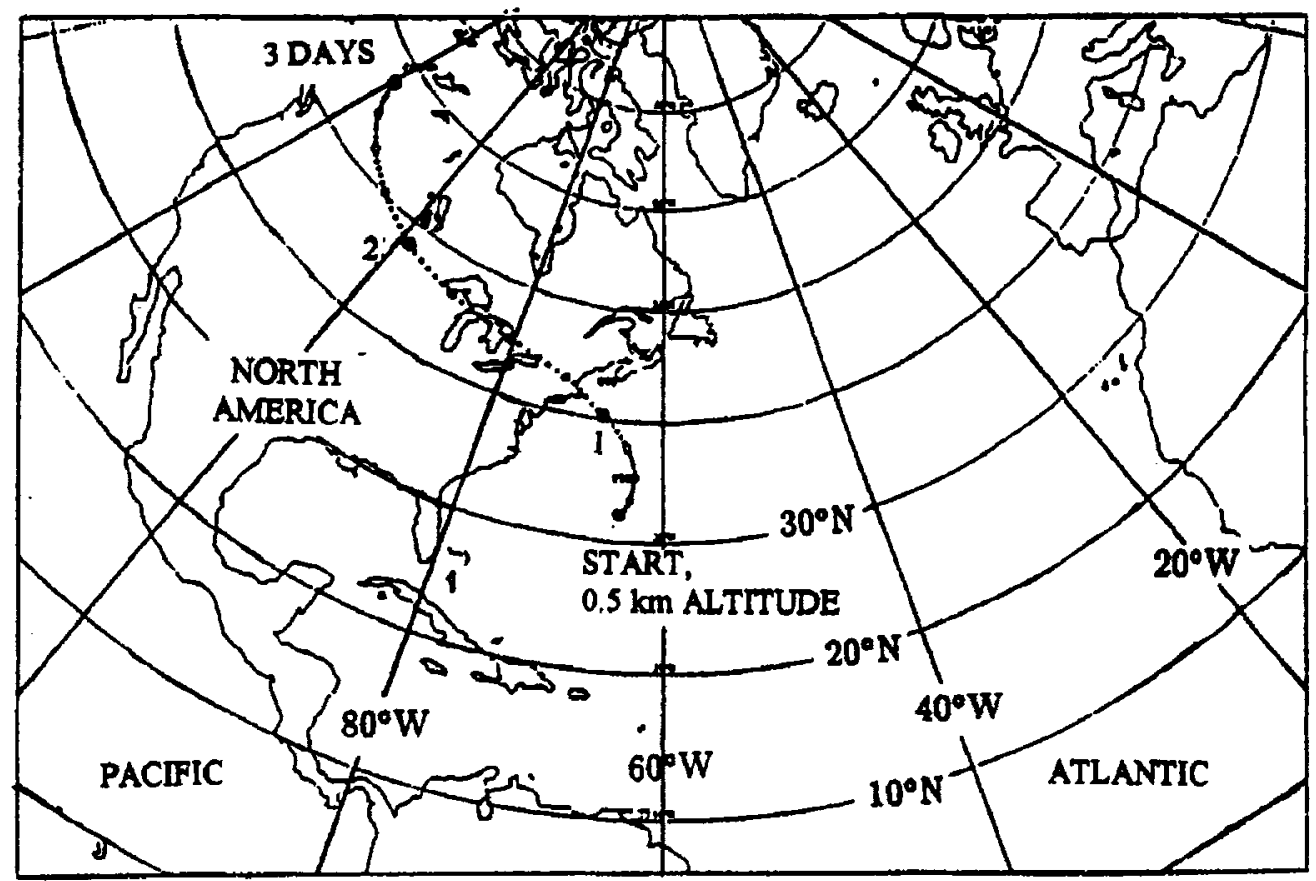

Figure 23. Three days backward trajectory calculation (performed by ECMWF) of the airmass sampled during the approach to Bermuda at $0.5 \mathrm{~km}(950 \mathrm{hPa})$ altitude in which CO mixing ratios up to $150 \mathrm{ppbv}$ are found.

air, creating a stratification with Southern Hemispheric air, having low CO mixing ratios, lying under CO-loaded airmasses which have been transported from the polluted boundary layer over the savanna, creating a vertical profile with high $\mathrm{CO}$ mixing ratios between $1.5-2 \mathrm{~km}$ altitude and lower mixing ratios below and above this layer.

The general structure of the vertical CO profiles observed over West Africa is very similar to those found by other researchers in tropical regions affected by biomass burning. In January 1979, Marenco and Delaunay (1980) performed CO vertical soundings over Ivory Coast and in August and September of 1979 and 1980 Crutzen et al. (1985) studied the vertical CO distribution over the Brazilian savanna region. Above the trade-wind inversion they found $\mathrm{CO}$-values of about $100 \mathrm{ppbv}$ and due to biomass burning the mixing ratios below this layer raised up to $300-400 \mathrm{ppbv}$. The profiles found here can be regarded as typical for tropical regions where biomass burning takes place. 


\subsection{MEASUREMENTS IN THE NORTHERN HEMISPHERE}

The measurements not discussed so far are from flights \#6 to \#9 (Halifax to Caracas, Figures $2 \mathrm{a}-3 \mathrm{~b}$ ) and the flights \#29 and \#30 (Las Palmas to Brétigny, Figures 17a17c). The profiles obtained near Point à Pitre (Figure 2c) and Caracas (Figure 3a) represent measurements performed in the northern tropics in unpolluted air. The $\mathrm{CO}$ mixing ratios vary between 80 and $100 \mathrm{ppbv}$ and no increase at lower altitudes can be seen. The profiles obtained at higher northern latitudes, near Bermuda (Figures $2 \mathrm{a}$ and 2b), Las Palmas (Figure 17a), Lisbon (Figure 17b), and Brétigny (Figure 17c) show increasing $\mathrm{CO}$ mixing ratios from about $100 \mathrm{ppbv}$ in the middle and upper troposphere to values of about $130-150 \mathrm{ppbv}$ at lower altitudes, showing the influence of strong sources of $\mathrm{CO}$ at the ground at these latitudes. In Figure $2 \mathrm{a}$, where the approach to Bermuda is depicted, the potential temperature indicates an inversion at $2 \mathrm{~km}$ altitude. Below this inversion the $\mathrm{CO}$ mixing ratios increase from $100 \mathrm{ppbv}$ to $150 \mathrm{ppbv}$. Trajectory calculations, depicted in Figure 23, show that the air parcel within the inversion layer near Bermuda had crossed the northwest of the United States. The high CO mixing ratios found near Bermuda can very probably be attributed to anthropogenic $\mathrm{CO}$ sources located in the densely populated regions in the northwest of the United States.

\subsection{MEASUREMENTS NEAR THE SOUTHERN HEMISPHERIC SUB-TROPICAL JET STREAM}

In Figure 24 flight data (altitude, wind direction, wind velocity, relative humidity and temperature) together with carbon monoxide and ozone mixing ratios (Marenco, 1996) are shown for a segment of flight \#17 (Comodoro Rivadavia to Buenos Aires). When flying at cruising altitude of $10.5 \mathrm{~km}$ a strong increase of ozone from about $50 \mathrm{ppbv}$ to more than $100 \mathrm{ppbv}$ was observed, and simultaneously the $\mathrm{CO}$ mixing ratio decreased from about $70 \mathrm{ppbv}$ to $50 \mathrm{ppbv}$. This is a clear indication for intrusion of stratospheric air into the troposphere. This interpretation is also supported by the low relative humidity (also depicted in Figure 24) within the $\mathrm{O}_{3}$ rich and $\mathrm{CO}$ poor airmass. The strong wind velocities, up to more than $50 \mathrm{~m} / \mathrm{s}$, indicate that these measurements are performed in the vicinity of the sub-tropical jet stream. The fall-off in the wind velocity near $36^{\circ} \mathrm{S}$ is due to reducing the flight altitude and thus leaving the core of the jet stream. We note that the stratospheric air intrusions are on the poleward side of the jet stream, as it is expected from Northern Hemispheric observations (Warneck, 1988).

$\mathrm{A} \mathrm{CO} / \mathrm{O}_{3}$-anticorrelation associated with stratospheric air intrusions was first observed in 1984 by Danielson et al. (1987), who studied a tropopause fold event over the United States. The measurements presented here are the first observations of $\mathrm{CO} / \mathrm{O}_{3}$-anticorrelations in stratospheric air intrusions in the Southern Hemisphere in combination with the sub-tropical jet stream. 
TROPOZ II FLight \# 17 Jan. 22. 1991

Comodoro Rtradaria (45'47'S;67'28' W) - Baesos Ares (34'48'S;58'32'W)

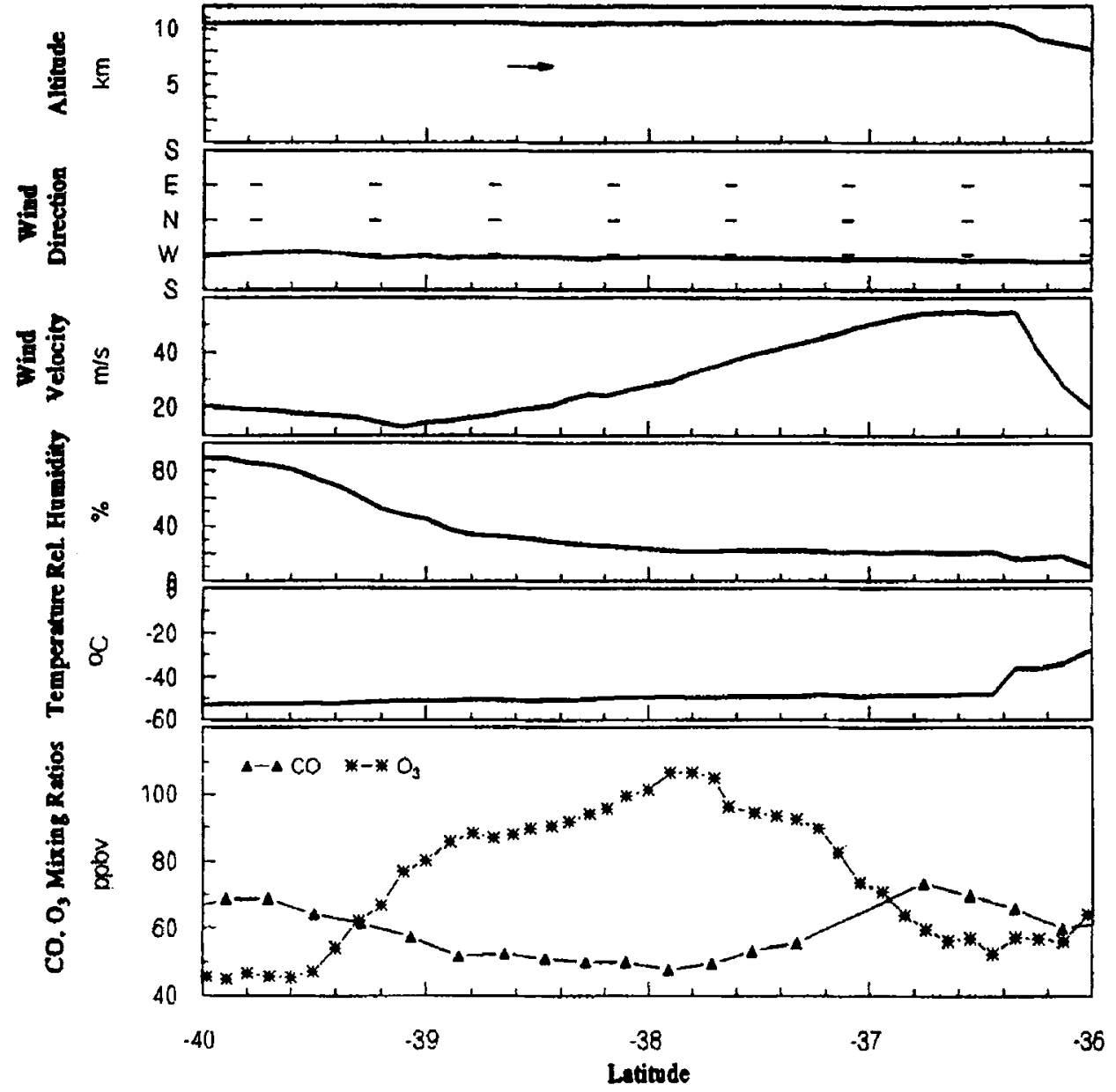

Figure 24. Segment of the horizontal flight path of flight \#17 (Comodoro Rivadavia-Buenos Aires) showing $\mathrm{CO} / \mathrm{O}_{3}$-anticorrelation in the vicinity of the Southern Hemispheric sub-tropical jet stream.

\section{Summary}

A summary representation of the $\mathrm{CO}$ data may be given in form of latitude-altitude cross sections. In the latitudinal-altitude plane the locations where data are taken are irregularly distributed. These data are projected to an regular grid, which has spacing of $10^{\circ}$ latitude and $1 \mathrm{~km}$ altitude. This is done by averaging for each grid point all datapoints located closer than $10^{\circ}$ latitude and $21 \mathrm{~km}$ altitude. A continuous two-dimensional distribution of the mixing ratio is created by interpolation between the grid points. In Figures $25 \mathrm{a}$ and $\mathrm{b}$ this distribution is represented by isolines of $\mathrm{CO}$ mixing ratio.

In Figure 25a a contour plot is shown which represents all $456 \mathrm{CO}$ measurements made during flights \#6 to \#15 (southbound flights). This represents a nearly merid- 
a)

FLIGHTS 6 - 15 (SOUTHBOUND)

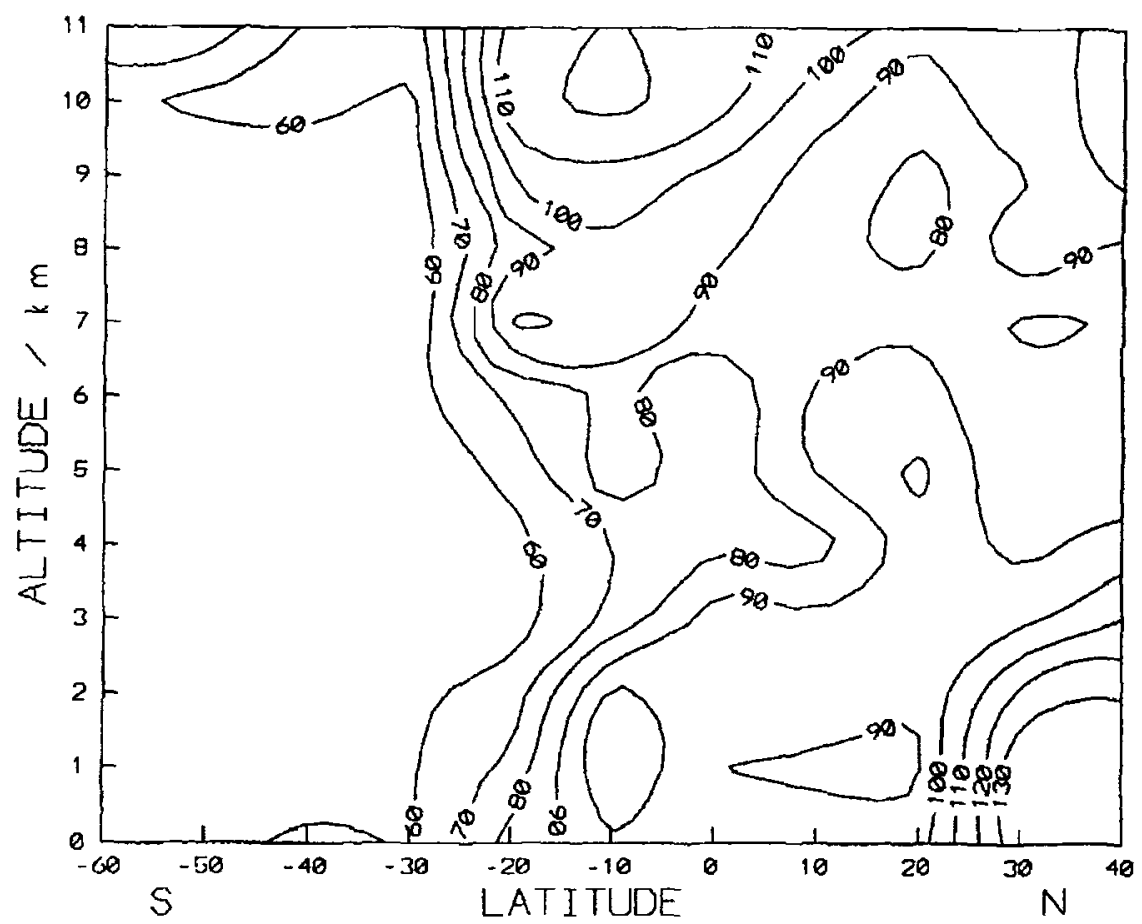

b) FLIGHTS $15-22$ and 27-30 (NORTHBOUND)

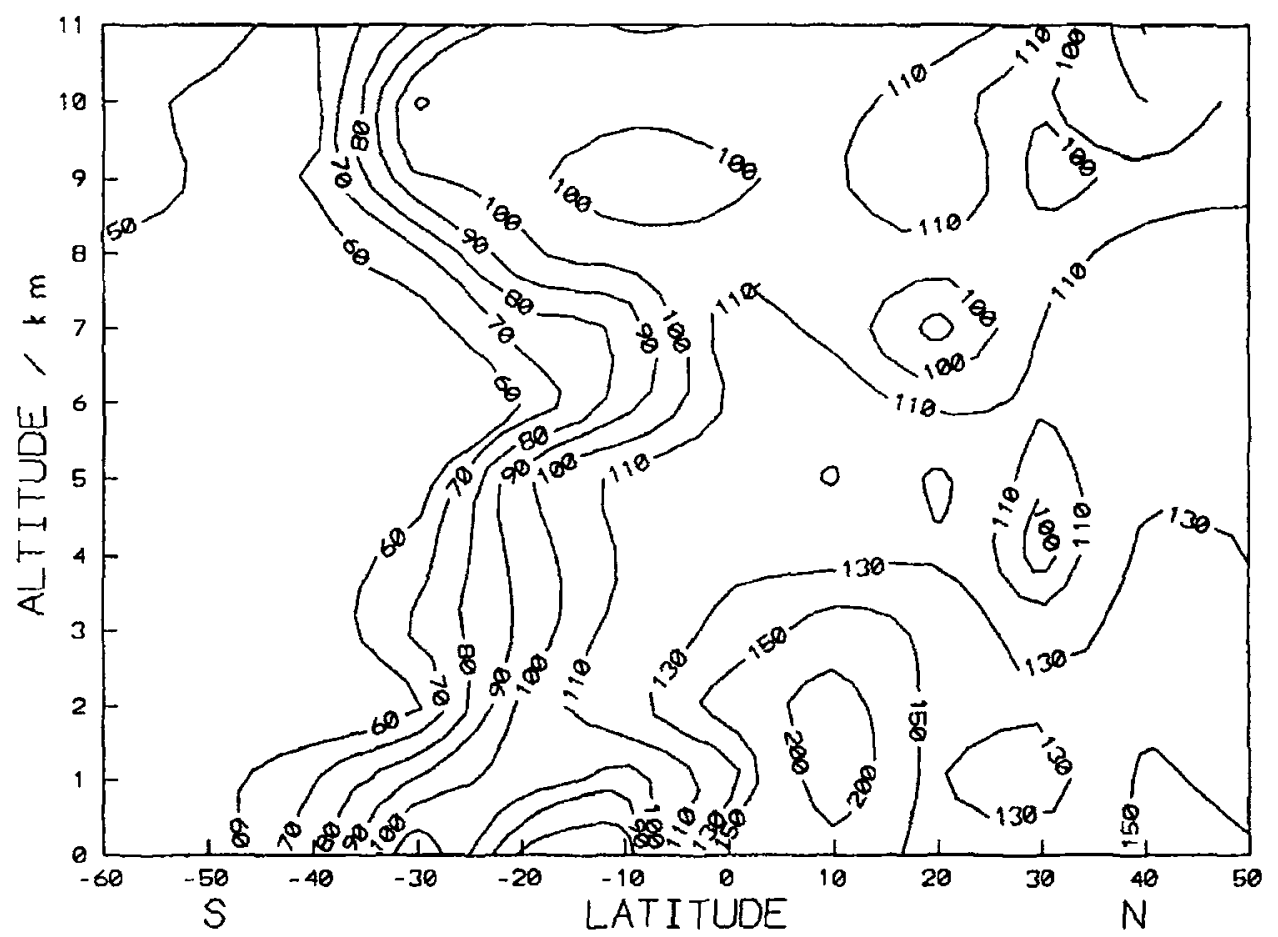

Figure 25. Two-dimensional distribution of $\mathrm{CO}$ as derived from (a) the southbound flights (fights $\# 6$ to \#15), and (b) the northbound flights (flights \#15 to \#22 and $\# 27$ to \#30). 
ional transect spreading between $64^{\circ} \mathrm{W}$ and $82^{\circ} \mathrm{W}$ longitude. Figure $25 \mathrm{~b}$ depicts the corresponding representation for 1298 measurements obtained during flights $\# 15$ to \#22 and \#27 to \#30 (the northbound flights) in the longitude range between $72^{\circ} \mathrm{W}$ and $2^{\circ} \mathrm{E}$. Flight $\# 25$ is omitted in order not to overemphasize the latitudinal range from $5^{\circ} \mathrm{N}-10^{\circ} \mathrm{N}$. It has to be noted that the two-dimensional representations depicted in Figures 25a and b represent only a snapshot in time 11-22 January for the southbound and 22 January-2 February for the northbound flights). Two measurements after take-off in Caracas, three data points before landing in Cali and three data points before landing in Santiago are rejected. For the northbound flights, three datapoints before landing in Rio de Janeiro and before landing in Brétigny are rejected, too. In the vicinity of airports very high $\mathrm{CO}$ mixing ratios were frequently observed due to local pollution. These data are not used since they are not representative of a cell of $10^{\circ}$ latitude and $1 \mathrm{~km}$ altitude.

A striking feature of both cross-sections is the large region in the south with very constant, low $\mathrm{CO}$ mixing ratios between 50 and $60 \mathrm{ppbv}$, as discussed in the previous section. The region with $\mathrm{CO}$ mixing ratios below $50 \mathrm{ppbv}$ at $55^{\circ}-60^{\circ} \mathrm{S}$ and at high altitudes in Figure 25b arises from the measurements performed within the tropopause. At about $40^{\circ}-20^{\circ} \mathrm{S}$ there is a strong north-south gradient in the $\mathrm{CO}$ mixing ratio. It extends over the entire troposphere from the surface to the tropopause. This gradient represents a transition from the spatially homogeneous region in the south to the rest of the troposphere. The CO rich airmass, found between $5^{\circ} \mathrm{N}$ and $30^{\circ} \mathrm{S}$ over South America, is depicted in Figures $25 \mathrm{a}$ and $\mathrm{b}$ as a high altitude tongue extending from the equator into the homogeneous region in the south. A very striking feature in Figure $25 \mathrm{~b}$ are the high $\mathrm{CO}$ values between $0^{\circ}$ and $20^{\circ} \mathrm{N}$ up to an altitude of $3 \mathrm{~km}$ caused by biomass burning in the West African savanna and obtained when flying under the trade wind inversion off the coast of West Africa. This illustrates the spatial extent of the influence of biomass burning on a regional scale. In the mid-latitude Northern Hemisphere free troposphere the mean mixing ratios of $\mathrm{CO}$ range between 100 and $130 \mathrm{ppbv}$ for the northbound flights. These values are somewhat higher than the corresponding values observed during the earlier southbound flights, where mixing ratios between 80 and $100 \mathrm{ppbv}$ were observed, showing the higher temporal and spatial variability of $\mathrm{CO}$ in the Northern Hemisphere. At low altitudes in the mid-latitude Northern Hemisphere the mean $\mathrm{CO}$ mixing ratio exceed $130 \mathrm{ppbv}$, indicating strong $\mathrm{CO}$ sources at the surface.

The data set discussed in this paper illustrates the complexity of the global chemistry of carbon monoxide. Carbon monoxide shows large variations in latitudinal, longitudinal and vertical directions. Different regions probed during the mission can be clearly distinguished, one shows a very homogeneous, on other a very heterogeneous distribution, a third region is dominated by interhemispheric exchange processes and a fourth is influenced by strong regional pollution. The data set presented here gives a coherent picture of part of the global distribution 
of $\mathrm{CO}$ which is of value for validation of aspects of three dimensional models of atmospheric chemistry.

\section{Acknowledgements}

The authors thank A. Marenco, Laboratoire d'Aérologie (CNRS), Toulouse, France, for organizing the TROPOZ II campaign and making his ozone and carbon monoxide data available. They also appreciate the valuable support which was given by the crew of the research aircraft, operated by the Centre d'Essais en Vole, Brétigny, France. This work was supported by the German Ministry of Research.

\section{References}

Brunke, E.-G., Scheel, H. E., and Seiler, W., 1990: Trends of tropospheric $\mathrm{CO}, \mathrm{N}_{2} \mathrm{O}$ and $\mathrm{CH}_{4}$ as observed at Cape Point, South Africa, Atmos. Environ. 24, 585-595.

Conrad, R., Seiler, W., Bunse, G., and Giehl, H., 1982: Carbon monoxide in sea water (Atlantic Ocean), J. Geophys. Res. 87, 8839-8852.

Crutzen, P. J., Delany, A. C., Greenberg, J., Haagenson, P., Heidt, L., Lueb, R., Pollock, W., Seiler, W., Wartburg, A., and Zimmermann P., 1985: Tropospheric chemical composition measurements in Brazil during the dry season, J. Atmos. Chem. 2, 233-256.

Crutzen, J. P. and Andreae, M. O., 1990: Biomass burning in the tropics: Impact on atmospheric chemistry and biogeochemical cycles, Science 250, 1669-1678.

Crutzen, P. J. and Zimmermann, P. H., 1991: The changing photochemistry of the troposphere, Tellus 43, 136-151.

Danielsen, E. F., Hipskind, R. S., Gaines, S. E., Sachse, G. W., Gregory, G. L., and Hill, G. F., 1987: Three-dimensional analysis of potential vorticity associated with tropopause folds and observed variations of ozone and carbon monoxide, J. Geophys. Res. 92, 2103-2111.

Dianov-Klokov, V. I. , Yurganov, L. N., Grechko, E. I., and Dzhola, A. V., 1989: Spectroscopic measurements of atmospheric carbon monoxide and methane. 1: Latitudinal distribution, J. Atmos. Chem. 8, 139-151.

Fraser, P., Coram, S., and Derenk, N., 1991: Baseline Atmospheric Program 1990, Div. of Atmospheric Research CSIRO, Melbourne.

Gauntner, D. J., Nyland, T., Tiefermann, M., and Dudzinski, T., 1979: Measurements of carbon monoxide, condensation nuclei, and ozone on a B 747SP aircraft flight around the world, Geophys. Res. Lett. 6, 167-170.

Harriss, R. C., Garstang, M., Wofsy, S. C., Beck, S. M., Bendura, R. J., Coelho, J. R. B., Drewry, J. W., Hoell, Jr. Matson, P. A., McNeal, R. J., Molion, L. C. B., Navarro, R. L., Rabine, V., and Snell, R. L., 1990a: The amazon boundary layer experiment: Wet season 1987, J. Geophys. Res. 95, $16721-16736$.

Harriss, R. C., Sachse, G. W., Hill, G. F., Wade, L. O., and Gregory, G. L., 1990b: Carbon monoxide over the Amazon Basin during the wet season, J. Geophys. Res. 95, 16927-16932.

Heidt, L. E., Krasnec, J. P., Lueb, R. A., Pollock, W. H., Henry, B. E., and Crutzen, P. J., 1980: Latitudinal distributions of $\mathrm{CO}$ and $\mathrm{CH}_{4}$ over the Pacific, J. Geophys. Res. 85, 7329-7336.

Hipskind, R. S., Gregory, G. L., Sachse, G. W., Hill, G. F., and Danielsen, E. F., 1987: Correlations between ozone and carbon monoxide in the lower stratosphere, folded tropopause, and maritime troposphere, J. Geophys. Res. 92, 2121-2130.

Hough, A. M., 1991: Development of a two-dimensional global tropospheric model: model chemistry, J. Geophys. Res. 96, 7325-7362.

Houghton, J. T., Callander, B. A., and Varney, S. K. (eds.), 1992: Climate Change 1992, Cambridge University Press.

Kirchhoff, V. W. J. H., and Marinho, E. V., 1990: Surface carbon monoxide measurements in Amazonia, J. Geophys. Res. 95, 16933-16943. 
Khalil, M. A. K. and Rasmussen, R. A., 1988: Carbon monoxide in the earth's atmosphere: Indications of a global increase, Nature 332, 242-245.

Khalil, M. A. K. and Rasmussen, R. A., 1994: Global decrease in atmospheric carbon monoxide concentration, Nature 370, 639-641.

Logan, J. A. , Prather, M. J., Wofsy, S. C., and McElroy, M. B., 1981: Tropospheric chemistry: A global perspective, J. Geophys. Res. 86, 7210-7254.

Marenco, A. and Delaunay, J. C., 1980: Experimental evidence of natural sources of $\mathrm{CO}$ from measurements in the troposphere, J. Geophys. Res. 85, 5599-5613.

Marenco, A., Macaigne, M., and Prieur, S., 1989: Meridional and vertical $\mathrm{CO}$ and $\mathrm{CH}_{4}$ distributions in the background troposphere $\left(70^{\circ} \mathrm{N}-60^{\circ} \mathrm{S} ; 0-12 \mathrm{~km}\right.$ altitude) from scientific aircraft measurements during the STRATOZ III experiment (June 1984), Atmos. Environ. 23, 185-200.

Marenco, A., 1996: TROPOZ II data set, in preparation.

Menaut, J.-C., Abbadie, L., Lavenu, F., Loudjani, P., and Podaire, A., 1991: Biomass burning in West African savannas, in J. S. Levine (ed.), Global Biomass Burning, MTT Press Cambridge, pp. 133-142.

Molion, L. C. B., 1987: On the dynamical climatology of the Amazon Basin and associated rainproducing mechanisms, in R. E. Dickinson (ed.), The geophysiology of Amazonia, Wiley, New York, pp. 391-407.

Novelli, P. C., Masarie, K. A., Tans, P. P., Lang, P. M., 1994: Recent changes in atmospheric carbon monoxide, Science 263, 1587-1589.

Pratt, R. and Falconer J., 1979: Circumpolar measurements of ozone, particles, and carbon monoxide from a commercial airliner, J. Geophys. Res. 84, 7876-7882.

Reichle, H. G., Connors, V. S., Holland, J. A., Hypes, W. D., Wallio, H. A., Casas, J. C., Gormsen, B. B., Saylor, M. S., and Hesketh, W. D., 1986: Middle and upper tropospheric carbon monoxide mixing ratios as measured by a satellite born remote sensor, J. Geophys. Res. 91, 10865-10887.

Reichle, H. G., Connors, V. S., Holland, J. A., Sherrill, R. T., Wallio, H. A., Casas, J. C., Condon, E. P., Gormsen, B. B., and Seiler, W., 1990: The distribution of middle tropospheric carbon monoxide during early October 1984: J. Geophys. Res. 95, 9845-9856.

Robinson, E., Clark, D., and Seiler, W., 1984: The latitudinal distribution of carbon monoxide across the pacific from California to Antarctica, J. Atmos. Chem. 1, 137-149.

Roths, J., 1992: Entwicklung eines flugtauglichen, laserspektroskopischen Spurengassensors und dessen Einsatz bei der TROPOZ II-Flugmeßkampagne, PhD Thesis, University of Mainz, (in German).

Roths, J., Zenker T., Parchatka, U. Wienhold F., and Harris G. W., 1996: FLAIR, a four laser airborne infrared spectrometer for atmospheric trace-gas measurements, in preparation.

Sanhueza, E., 1991: Effects of vegetation burning on the atmospheric chemistry of the Venezuelan savanna, in J. S. Levine (ed.), Global Biomass Burning, MIT Press, Cambridge, pp. 122-125.

Scheel, H. E., Brunke, E.-G., and Seiler, W., 1990: Trace gas measurements at the monitoring station Cape Point, South Africa, between 1978 and 1988, J. Atmos. Chem. 11, 197-210.

Seiler, W. and Junge, C., 1969: Decrease of carbon monoxide mixing ratio above the polar tropopause, Tellus, 21, 447-449.

Seiler, W., and Warneck, P., 1972: Decrease of carbon monoxide mixing ratio at the Tropopause, $J$. Geophys. Res. 77, 3204-3214.

Seiler, W., 1974: The cycle of atmospheric CO, Tellus 26, 116-135.

Seiler, W. and Fishman, J., 1981: The distribution of carbon monoxide and ozone in the free troposphere, J. Geophys. Res. 86, 7255-7265.

Seiler, W., Giehl, H., Brunke, E.-G., and Halliday, E., 1984: The seasonality of $\mathrm{CO}$ abundance in the Southern Hemisphere, Tellus 36 B, 219-231.

Warneck, P., 1988: Chemistry of the Natural Atmosphere, Int. Geophys. Ser. 41, Academic Press, San Diego.

Wilkniss, P. E., Lamontagne, R. A., Larson, R. E., Swinnerton, J. W., Dickson, C. R., and Thompson, T., 1973: Atmospheric trace gases in the Southern Hemisphere, Nature 245, 45-47.

Wolz, G., 1991: private communication. 
Zander, R., Demoulin, P., Ehalt, D. H., Schmidt, U., and Rinsland, C. P., 1989: Secular increase of the total vertical column abundance of carbon monoxide above central Europe since 1950, J. Geophys. Res. 94, 11021-11028. 